\title{
HYDROGEOLOGY OF A LANDFILL, PINELLAS COUNTY, FLORIDA
}

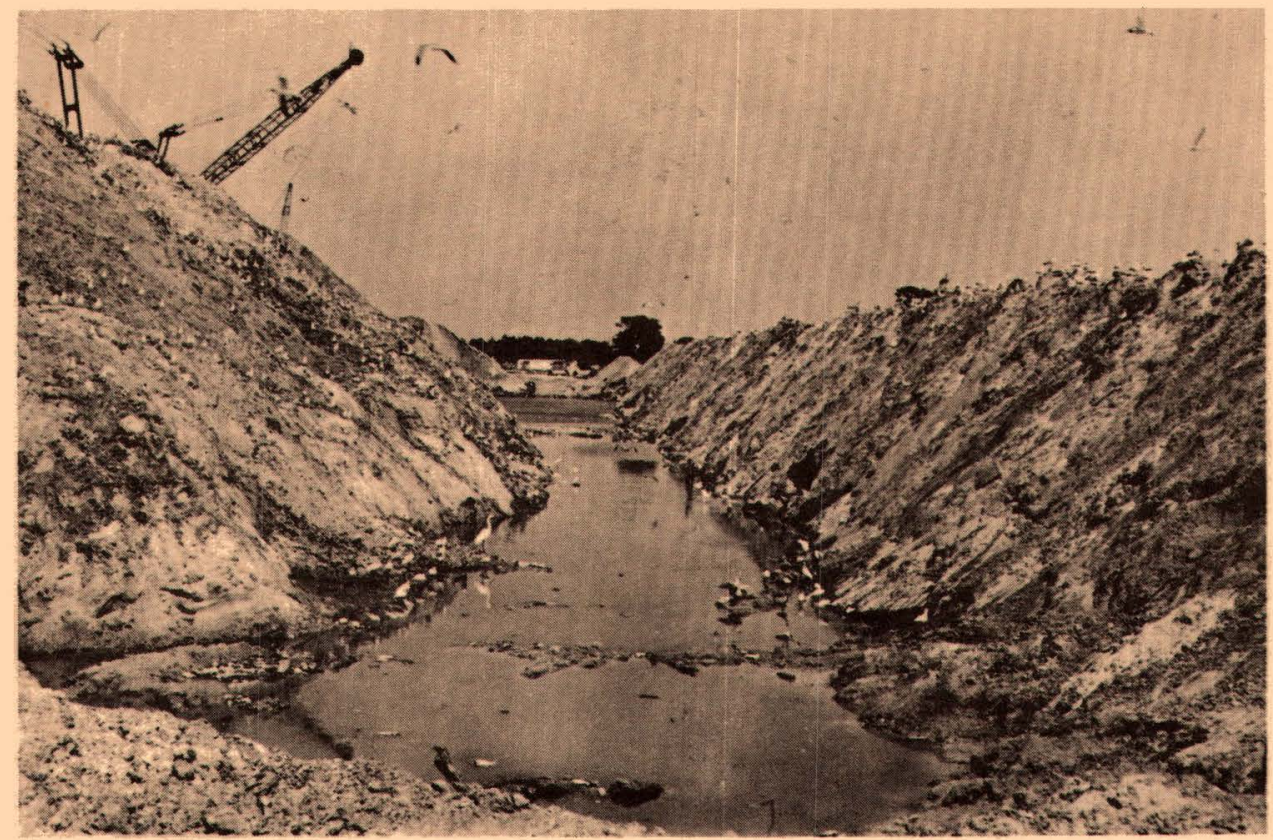

U.S. GEOLOGICAL SURVEY

WATER-RESOURCES INVESTIGATIONS 82-30

Prepared in cooperation with

PINELLAS COUNTY, FLORIDA

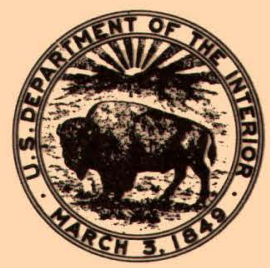




\begin{tabular}{|c|c|}
\hline $\begin{array}{l}\begin{array}{l}\text { REPORT DOCUMENTATION } \\
\text { PAGE }\end{array} \\
\text { 1,-REPORT NO. }\end{array}$ & 3. Recipient's Accession No. \\
\hline \multirow{2}{*}{$\begin{array}{l}\text { 4. Title and Subtitle } \\
\text { HYDROGEOLOGY OF A LANDFILL, PINELLAS COUNTY, FLORIDA }\end{array}$} & $\begin{array}{l}\text { 5. Report Date } \\
\text { March } 1983\end{array}$ \\
\hline & 6. \\
\hline $\begin{array}{l}\text { 7. Author(s) } \\
\text { Mario Fernandez, Jr. }\end{array}$ & $\begin{array}{l}\text { 8. Performing Organization Rept. No. } \\
\text { USGS/WRI } 82-30\end{array}$ \\
\hline 9. Performing Organization Name and Address & 10. Project/Task/Work Unit No. \\
\hline $\begin{array}{l}\text { U.S. Geological Survey, Water Resources Division } \\
325 \text { John Knox Road, Suite F- } 240 \\
\text { Tallahassee, Florida } 32303\end{array}$ & $\begin{array}{l}\text { 11. Contract(C) or Grant(G) No. } \\
\text { (C) } \\
\text { (G) }\end{array}$ \\
\hline 12. Sponsoring Organization Name and Address & 13. Type of Report \& Period Covered \\
\hline $\begin{array}{l}\text { U.S. Geological Survey, Water Resources Division } \\
325 \text { John Knox Road, Suite F-240 } \\
\text { Tallahassee, Florida } 32303\end{array}$ & \\
\hline
\end{tabular}

\section{Supplementary Notes}

Prepared in cooperation with Pinellas County, Florida

\section{Abstract (Limit: 200 words)}

The Pinellas County landfill site is on a flat, coastal area characterized by a nearsurface water table. Part of the site is subject to tidal flooding; altitudes within the study area range from 8 to 12 feet above sea level.

Three geohydrologic units underlie the landfill site. In descending order, these are: a surficial aquifer about 19 feet thick composed of sand and she11, a confining bed about 35 feet thick composed of marl and clay, and the Floridan aquifer composed of limestone. Landfill operations have not altered surface-water quality. Although leachate movement downward into the Floridan aquifer is not indicated, vertical movement through the confining bed is about 0.005 foot per year. The rate of lateral movement of ground-water away from the site is about 1.2 feet per year; however, the rate of movement along the boundary from the oldest section of the landfill through the surficial aquifer is about 20 feet per year. Peaks in concentration of selected chemical parameters and flow-rate analysis of water from trenches indicate the possibility of intermittent release of leachate from the landfill.

\section{Document Analysis a. Descriptors}

Sanitary landfills, Leachates, Water-table gradient, Water quality, Water-table wells

b. Identifiers/Open-Ended Terms

Leachate migration, Heavy metals, Nutrients, Surficial aquifer, Pinellas County, Florida

c. COSATI Field/Group

\begin{tabular}{|l|l|l|}
\hline $\begin{array}{l}\text { 18. Availability Statement } \\
\text { No restriction on distribution }\end{array}$ & $\begin{array}{c}\text { 19. Security Class (This Report) } \\
\text { UNCLASSIFIED }\end{array}$ & $\begin{array}{l}\text { 21. No. of Pages } \\
\text { 41 }\end{array}$ \\
\cline { 2 - 4 } & $\begin{array}{c}\text { 20. Security Class (This Page) } \\
\text { UNCLAS SIFIED }\end{array}$ & $\begin{array}{l}\text { 22. Price } \\
\text { (See ANSI-Z39.18) }\end{array}$ \\
\hline
\end{tabular}


HYDROGEOLOGY OF A LANDFILL, PINELLAS COUNTY, FLORIDA

By Mario Fernandez, Jr.

U.S. GEOLOGICAL SURVEY

Water-Resources Investigations 82-30

Prepared in cooperation with

PINELLAS COUNTY, FLORIDA

Tallahassee, Florida

1983 


\author{
UNITED STATES DEPARTMENT OF THE INTERIOR \\ JAMES G. WATT, Secretary \\ GEOLOGICAL SURVEY \\ Dallas L. Peck, Director
}

For additional information write to:

U.S. Geological Survey

Suite 3015, Hobbs Federal Center

227 North Bronough Street

Tallahassee, Florida 32301 


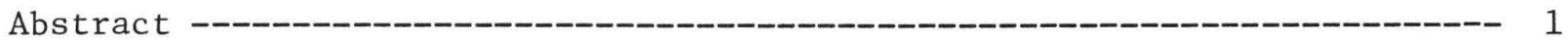

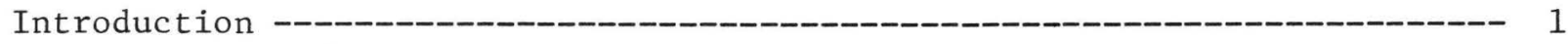

Purpose and scope --_-_-_-_-_-_-_-_-_-_-_-_-_-_-_-_-_-_---- 2

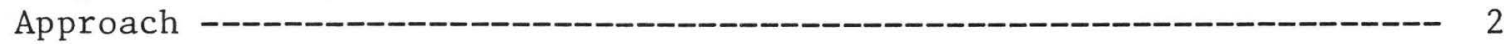

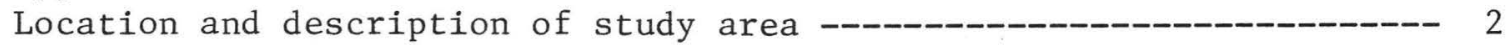

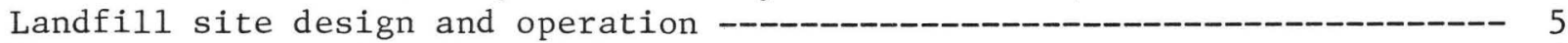

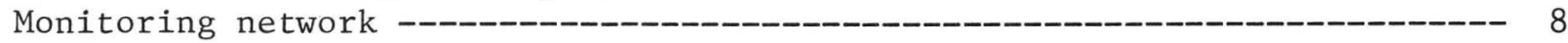

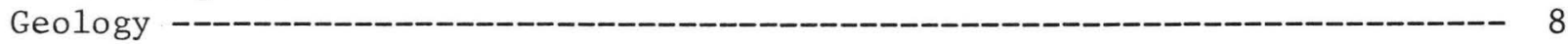

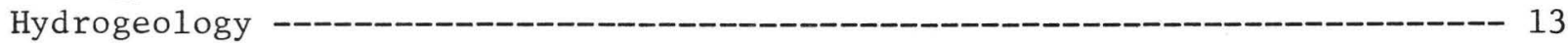

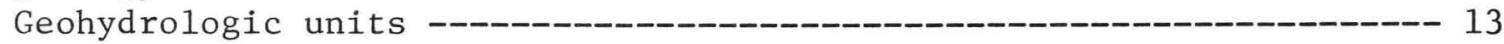

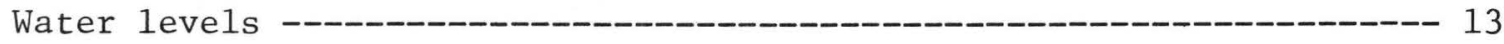

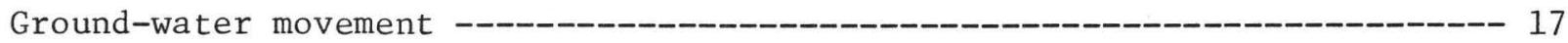

Horizontal movement --_-_-_-_-_-_-_-_-_-_-_-_-_-_-_-_-_-_-_-_-_--- 17

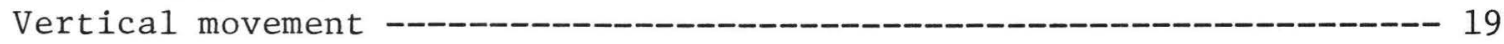

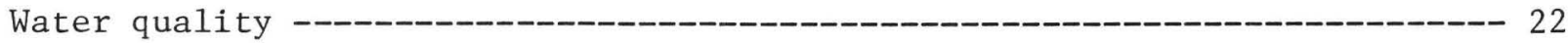

Effects of leachate on water quality --_-_-_-_-_-_-_-_-_-_-_-_-_----- 27

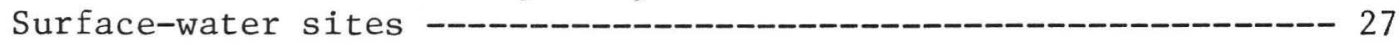

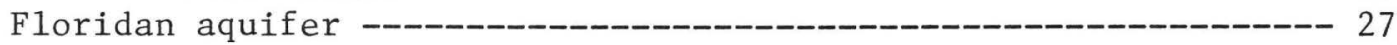

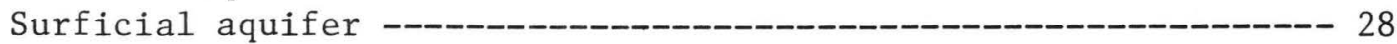

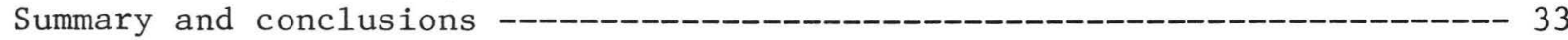

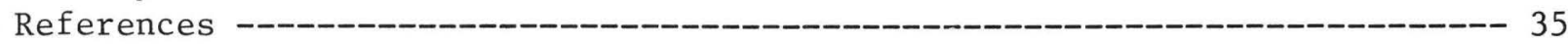

\section{ILLUSTRATIONS}

Figure 1. Map showing generalized regional study area and boundaries of the 100-year tidal flood -----------------------

2. Photograph showing aerial view of Pinellas County landfill and surrounding area ---_---_--- 4

3. Map showing the design of the Pinellas County landfill ------- 6

4. Diagram showing example of landfilling method used at the Pinellas County landfill --_--_- 7

5. Map showing location of ground-water and surface-water monitoring sites, Pinellas County landfill ------------- 9

6. Index map and geologic fence diagram of Pinellas County land-

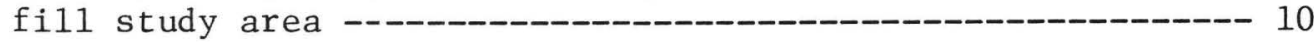

7. Diagram showing generalized hydrogeologic section at the

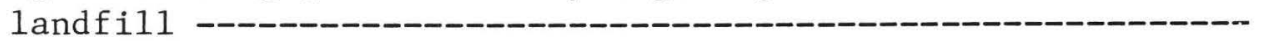

8. Map showing water-level altitudes in the surficial aquifer, May and September 1977 ----------------

9. Map showing generalized regional configuration of the water level in the surficial aquifer showing direction of groundwater movement 


\section{ILLUSTRATIONS--Continued}

Figure 10. Diagram showing generalized geologic column showing thickness of each layer and corresponding hydraulic conductivity and

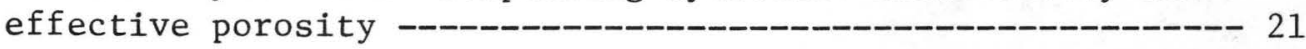

11. Diagram of generalized geologic section showing time required for contaminants to migrate vertically from landfill trenches to the Floridan aquifer

12. Map showing location of ground-water and surface-water quality sampling sites

13. Graphs showing variations in selected water-quality parameters with time for wells along 118th Avenue North ------------- 31

14. Map showing direction of leachate movement from site A, September 1977

Table 1. Relation of geologic formations and geohydrologic units ----
2. Physical characteristics of selected geologic samples ---
3. Background and trench water quality compared to recommended

4. Comparison of water-quality data for a Floridan aquifer well (5b1) located within the landfill to water-quality data for wells (S2, S3, S4) completed in the same strata 10 miles west of the landfill

5. Statistics of selected parameters for water from selected wells and old and new trenches

6. Statistics of trace metals in water from selected wells and trenches 


\section{ABBREVIATIONS AND CONVERSION FACTORS}

Factors for converting inch-pound units to International System (SI) of metric units and abbreviations of units

$\underline{\text { Multiply }}$

inch (in)

mile (mi)

acre

square foot $\left(f \mathrm{t}^{2}\right)$

cubic foot $\left(\mathrm{ft}^{3}\right)$

gallon (ga1)

pound (1b)

ton, short
$\underline{B y}$

$$
\begin{gathered}
25.40 \\
1.609 \\
4,047 \\
0.09290 \\
0.02832 \\
3.785 \\
0.453 \\
0.9072
\end{gathered}
$$

To obtain

millimeter (mm)

kilometer $(\mathrm{km})$

square meter $\left(\mathrm{m}^{2}\right)$

square meter $\left(\mathrm{m}^{2}\right)$

cubic meter $\left(\mathrm{m}^{3}\right)$

liter (L)

kilogram (kg)

megagram (Mg)

National Geodetic Vertical Datum of 1929 (NGVD of 1929).--A geodetic datum derived from a general adjustment of the first-order level nets of both the United States and Canada, formerly called mean sea level. NGVD of 1929 is referred to as sea level in the text of this report.

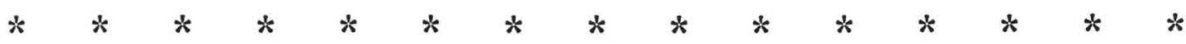





\title{
HYDROGEOLOGY OF A LANDFILL, PINELLAS COUNTY, FLORIDA
}

By Mario Fernandez, Jr.

\begin{abstract}
The Pinellas County landfill site is on a flat, coastal area characterized by a near-surface water table. Part of the site is subject to tidal flooding; altitudes within the study area range from 8 to 12 feet above sea level.

Three geohydrologic units underlie the landfill site. In descending order, these are: a surficial aquifer about 19 feet thick composed of sand and shell, a confining bed about 35 feet thick composed of marl and clay, and the Floridan aquifer composed of limestone.

Landfill operations have not altered surface-water quality. Although leachate movement downward into the Floridan aquifer is not indicated, vertical movement through the confining bed is about 0.005 foot per year. The rate of lateral movement of ground-water away from the site is about 1.2 feet per year; however, the rate of movement along the boundary from the oldest section of the landfill through the surficial aquifer is about 20 feet per year. Peaks in concentration of selected chemical parameters and flow-rate analysis of water from trenches indicate the possibility of intermittent release of leachate from the landfill.
\end{abstract}

\section{INTRODUCTION}

The Pinellas County landfill, located in east-central Pinellas County, handles about 540 tons of refuse each collection day. Solid waste from municipal collection systems and private collectors is deposited Monday through Saturday. The solid waste is buried in V-shaped trenches excavated to a depth of 25 to 30 feet through surficial sand and into marl. The individual trenches must be dewatered during the filling operation due to the high water table.

The U.S. Geological Survey and Pinellas County entered into a cooperative study to determine baseline water-quality conditions and to evaluate the effects of landfill leachate on the quality of surface and ground water. Data collection for the investigation began in May 1975 and ended in October 1977. The results of the data-collection phase of the investigation are released in U.S. Geological Survey Open-File Report 78-822 entitled "Water-Quality Data from a Landfill, Pinellas County, Florida, May 1975-October 1977," by Mario Fernandez, Jr. (1979b). 
Purpose and Scope

The purpose of this investigation was to determine the effects of land disposal of solid waste on the quality of ground and surface water in a coastal area with a near-surface water table.

This report presents the results of test drilling and analysis of water withdrawn from selected wells drilled into the surficial aquifer. Drillers' logs for 76 wells and laboratory analysis of corings from 2 selected wells were used to identify the geologic and hydrologic properties of the overburden. Water-level measurements and data on physical properties of the overburden were used to aid in determining the lateral and vertical migration of the leachate.

\section{Approach}

Seventy-six test holes and observation wells were drilled in order to determine the hydrology and geology of the area. A program of monitoring ground and surface water was initiated prior to deposition of solid waste to establish baseline water-quality conditions. Chemical analyses of water samples were made to determine concentrations of major ions, heavy metals, nutrients, biochemical oxygen demand $\left(\mathrm{BOD}_{5}\right)$, chemical oxygen demand (COD), coliform bacteria, herbicides, and pesticides, before and during landfill operations. Soil samples from test holes were collected for laboratory determinations of porosity, ion-exchange capacity, grain-size distribution, hydraulic conductivity, and clay-mineral identification. Water levels were measured in wells to determine the depth to ground water and water-level changes during landfill operations. Water-table contour maps for the wet and dry seasons were prepared from which the direction of ground-water movement was determined.

\section{Location and Discription of Study Area}

The Pinellas County landfill is located about 2 miles west of 0ld Tampa Bay and about 7 miles north of St. Petersburg (fig. 1). Soils at the landfill are of the Elrod, Felda, and Wabasso soil series (U.S. Department of Agriculture, 1972). These poorly developed soils occur in areas characterized by a nearsurface water table subject to flooding. Such soils are generally considered to be unsuitable for landfills because of possible adverse impacts on groundwater quality (Stewart and Duerr, 1973). The study area is nearly level and is covered with palmetto and scrub pine. Land-surface altitudes range from 8 to 12 feet above sea level. Shallow drainage ditches on an approximately quartersection pattern drain to the northwest into 0ld Tampa Bay. Part of the site is subject to tidal flooding (fig. 1). The tidal flood elevation ( 8 feet above sea leve1) is the altitude that tidal flooding is expected to reach on an average of once every 100 years. The flood-prone area shown in figure 1 has a 1percent chance of being inundated during any 1 year (U.S. Geological Survey, $1973 a ; 1973 b)$.

The Pinellas County landfill is in an area of mixed land use comprised of light industry, private homes, and waste-disposal sites (fig. 2). The landfill proper covers about 560 acres of the approximately 1,000 acres included in the 


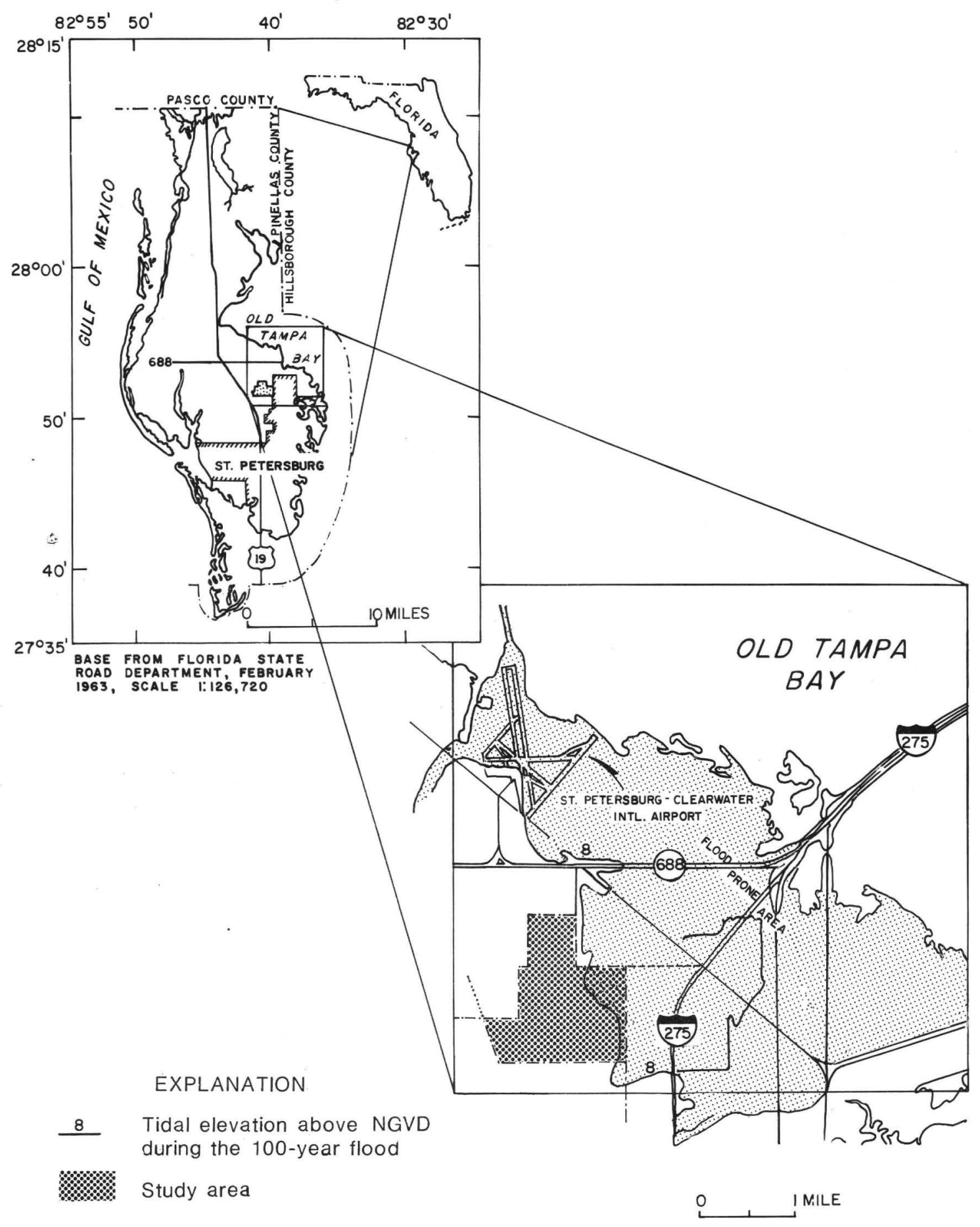

Figure 1.--Generalized regional study area and boundaries of the 100-year tidal flood. 


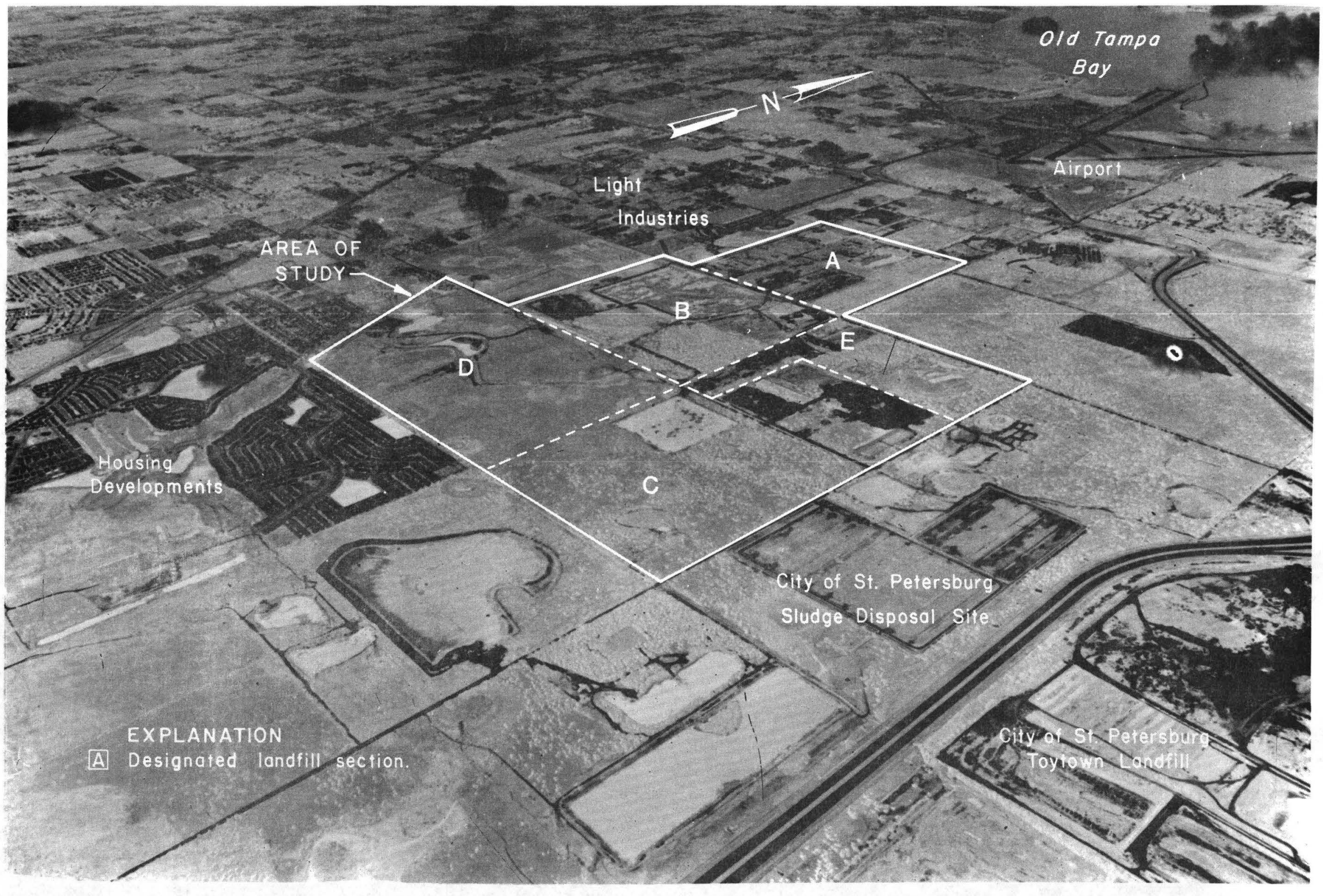

Figure 2.--Aerial view of Pinellas County landfill and surrounding area. 
study area. The study area has been divided into five sections for the purpose of identification (fig. 3). Sections A, B, and C comprise the landfill. Section $A$ is the original landfill; section B has been altered by borrow pits and has one small area where waste has been buried; section $C$ is reserved for future expansion; section $\mathrm{D}$ is a private, undeveloped tract altered by artificial lakes; and section $\mathrm{E}$ is a private landfill.

Pinellas County has a subtropical climate characterized by warm, humid summers with afternoon thundershowers and by mild, dry winters with occasional showers associated with cold fronts. The normal yearly rainfall, based on the period 1941-70, is 54.90 inches. Some rainfall generally occurs during each month of the year, but about 70 percent occurs between June and October. The greatest monthly rainfall during the period of study was 17.8 inches in August 1976. The average annual precipitation for the period of rainfall-data collection, November 1974 through June 1978, was 48 inches.

Heavy rains have flooded the area due to poor natural drainage. For example, during June 22-24, 1974, about 20 inches of rain fell in St. Petersburg. Extensive flooding of the landfill site and surrounding area was reported by landfill operators.

The average annual temperature for the area is about $73.5^{\circ} \mathrm{F}$. Average monthly temperatures range from $61^{\circ} \mathrm{F}$ in January to $82^{\circ} \mathrm{F}$ in August.

\section{LANDFILL SITE DESIGN AND OPERATION}

The Pinellas County landfill encompasses an area of about 560 acres. The landfill layout, designated sections, and approximate number, location, and configuration of landfill trenches are shown in figure 3. Section A, about 160 acres in size, is between two drainage ditches in the northern part of the landfill. Landfilling operation began at this site in 1963 and continued to November 1975. From November 1975 through October 1977, landfilling operations took place in the southwest corner of section B. After October 1977, active operations moved southeastward to section C. A private landfilling operation is located in section $E$, east of section $B$.

Solid waste from municipal collection systems and private collectors is deposited Monday through Saturday. The operation handles about 13,000 tons of solid waste per month, or about 540 tons during each collection day. The waste consists of municipal garbage, trash, brush, and construction debris. The solid waste is buried in V-shaped trenches ranging from 100 to 200 feet in width, 500 to 1,000 feet in length, and 25 to 30 feet in depth, dug into sand and marl. The depth of excavation is controlled by the plasticity of the marl. The trenches are excavated with a dragline and the overburden is deposited next to the trenches. The individual trenches must be dewatered during filling due to the high water table. An example of the area landfilling method and a generalized geohydrologic section of the study area are presented in figure 4.

After the trenches are filled, landfill operations then shift to the area method of disposal in which solid waste is deposited to heights of about 25 feet above land surface. The solid waste is covered daily with about 1 foot of soil and the final cover with 2 feet of soil. The area method of disposal was not used at section A. 


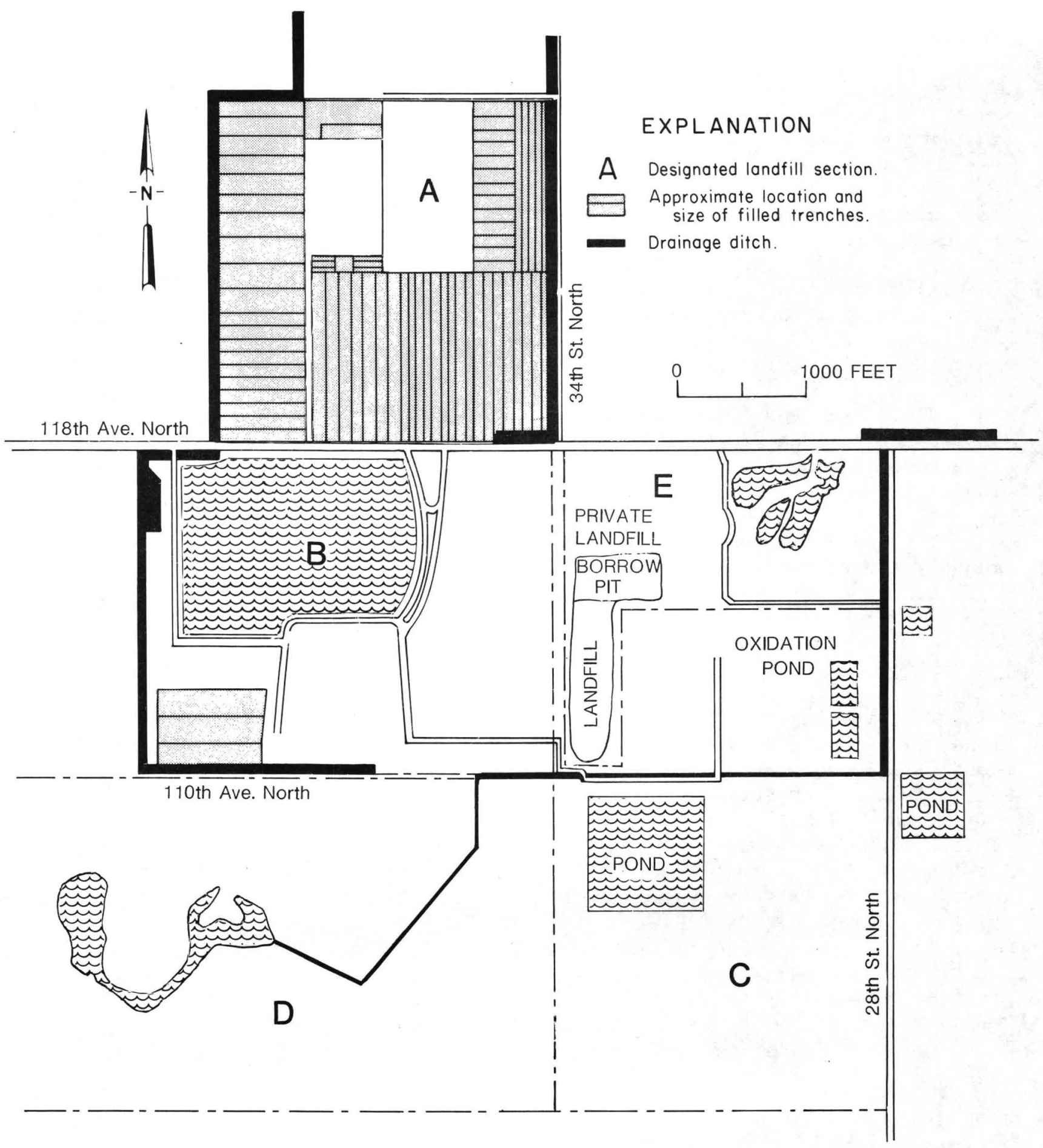

Figure 3.--Design of the Pinellas County landfill. 


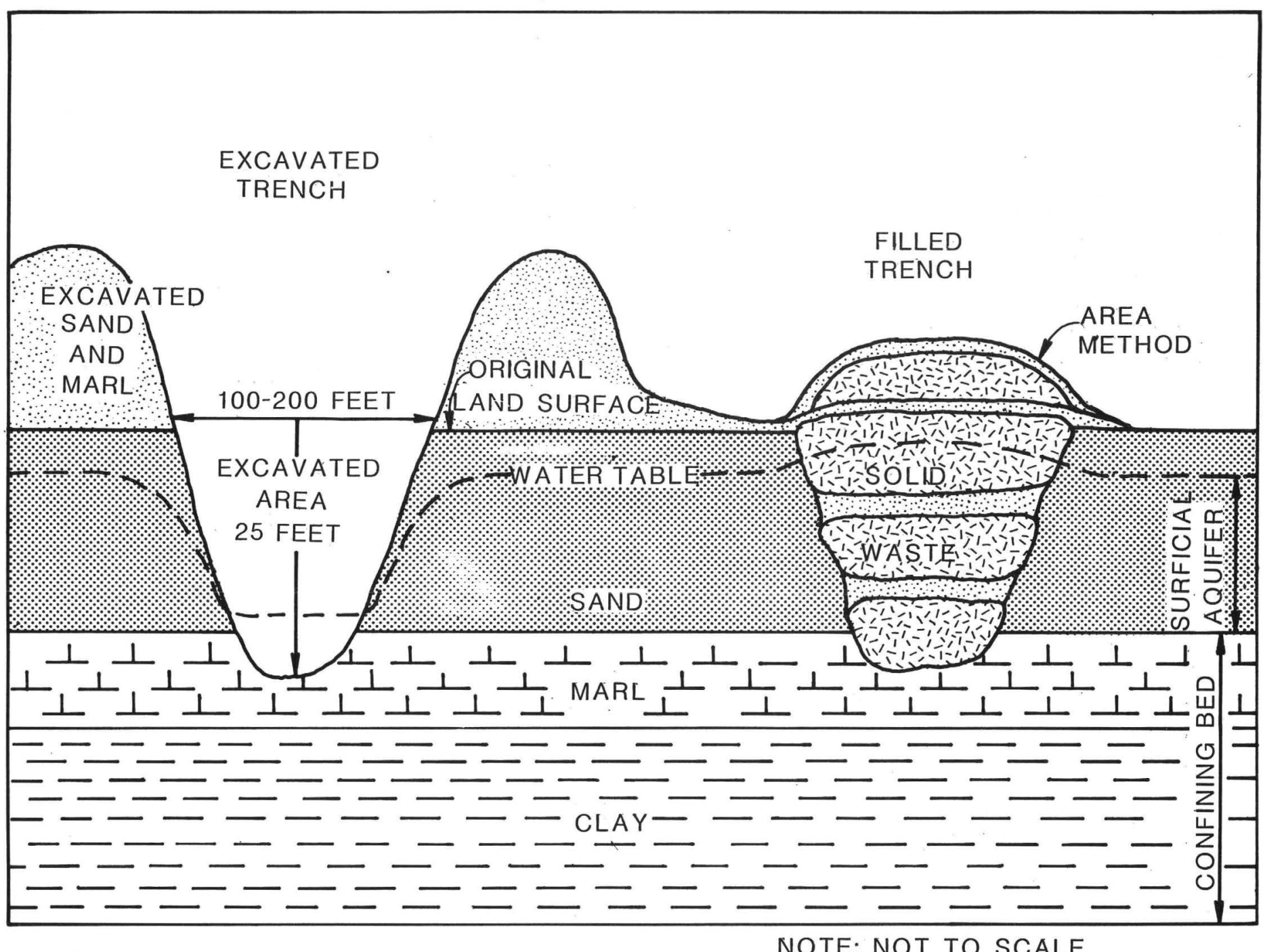

Figure 4.--Example of landfilling method used at the Pinellas County landfill. 


\section{MONITORING NETWORK}

A network of test holes was drilled and wells established to obtain: lithologic samples to determine physical properties of the geologic units, (2) hydrologic information to develop water-table maps, and (3) chemical and microbiological water-quality data to define baseline conditions and changes that occurred due to landfill operations. Seventy-six test holes were drilled into the surficial aquifer at the Pinellas County landfill site (sections A, B, and C) and in sections $\mathrm{D}$ and $\mathrm{E}$ for water-level monitoring. Two wells, SF-26 and SF-62, from another study (Fernandez, 1979a) were also used for water-level monitoring. Selected wells were used for water-quality sampling. Four surfacewater gaging stations were established to obtain data on surface-water quality and water levels in the drainage ditches; 22 additional sites were established for water-level (stage) determinations only. Locations of the monitoring sites are shown in figure 5 .

Test holes were drilled using a hollow-stem auger. Wells were constructed in the test holes using 2-inch PVC pipe finished with 1.5- or 2-inch PVC screen. Well depths ranged from 5 to 31 feet, and screen lengths ranged from 2.5 to 10 feet. Seven clusters, consisting of six wells ranging in depth from 5 to 25 feet, were installed to determine the vertical migration of water in the surficial aquifer. One of the six wells in each cluster was a 15-foot-deep well finished with 10 feet of 1.5-inch perforated screen for water-level monitoring and water-quality sampling from the depth interval of 5 to 15 feet. Descriptions of the wells, surface-water monitoring sites, and logs of selected wells were released in a previous report (Fernandez, 1979b).

Wells 10 through 13 and 16 through 20 were used to establish background water-quality conditions unaffected by the landfill operation. Surface-water sites SW-2 and SW-3 were also used to establish background conditions. Wells $\mathrm{SF}-26, \mathrm{SF}-62$, and $23 \mathrm{a}$ were used to establish downgradient ground-water-quality conditions of the landfill. We1ls $8 \mathrm{a}, 8 \mathrm{~b}, 8 \mathrm{c}, 14$, and 15 and surface-water sites SW-1 and SW-4 were established to monitor migration of leachate in ground water from trenches in the southeast corner of section B. Wells 1 through 4 and wells 7, 21, and 22 were established to determine the extent of leachate in ground-water movement from trenches in section A.

\section{GEOLOGY}

The lithology of deposits underlying the study area was determined from samples obtained from the test drilling. A generalized lithologic cross section of the Pinellas County landfill is presented in figure 6. Three geologic formations (table 1) were penetrated during the drilling: (1) undifferentiated surficial deposits, (2) Hawthorn Formation, and (3) upper part of the Tampa Limestone. Similar deposits were described for a nearby site by Heath and Smith (1954) and Hutchinson and Stewart (1978).

Selected physical properties of the sand, marl, and clay deposits are presented in table 2. Grain-size analyses, porosity (total and effective), hydraulic conductivity (vertical and horizontal), and cation-exchange properties were determined from split-spoon samples by the U.S. Geological Survey hydrologic laboratories in Denver, Colo. 


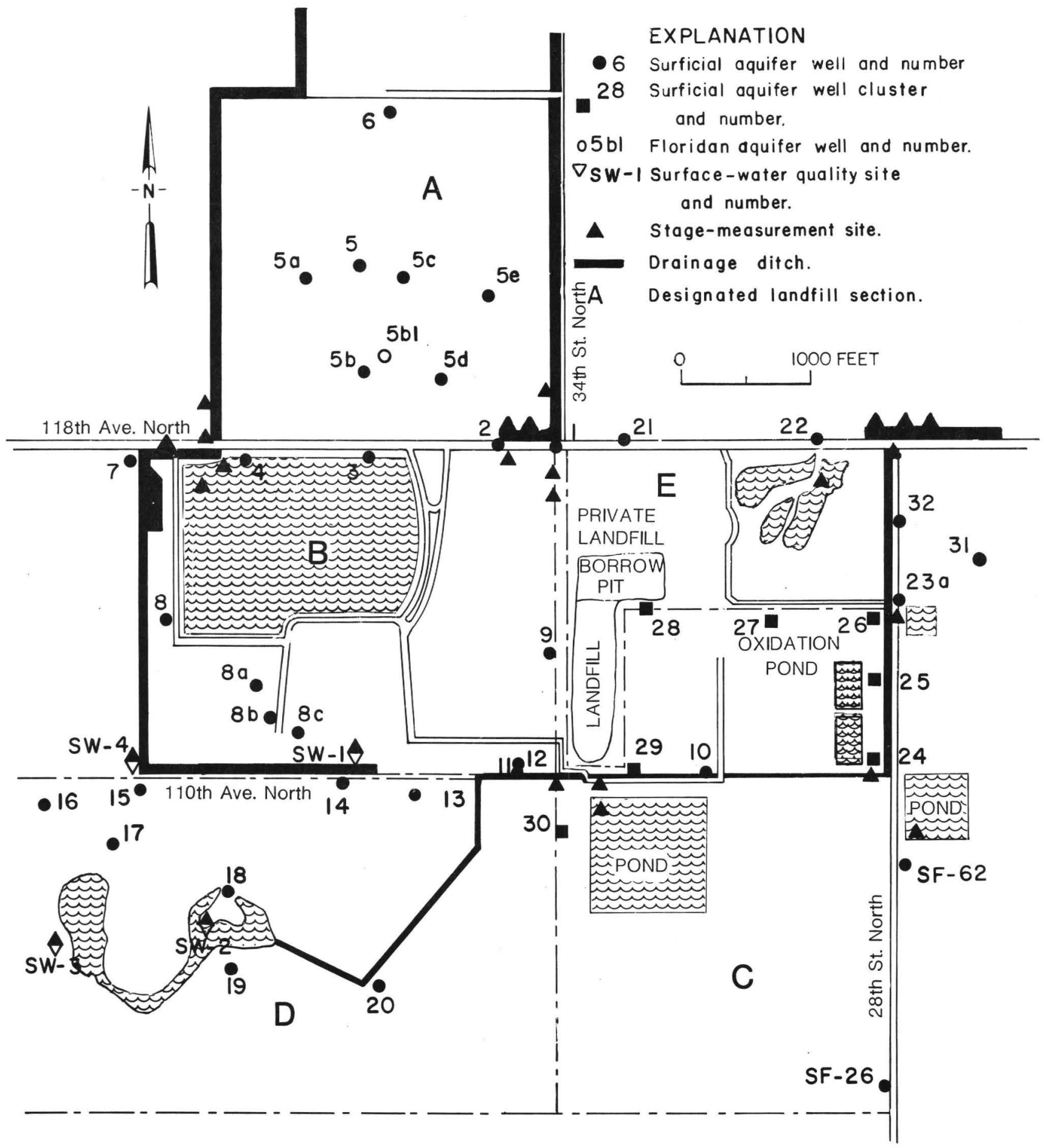

Figure 5.--Location of ground-water and surface-water monitoring sites, Pinellas County landfill. 


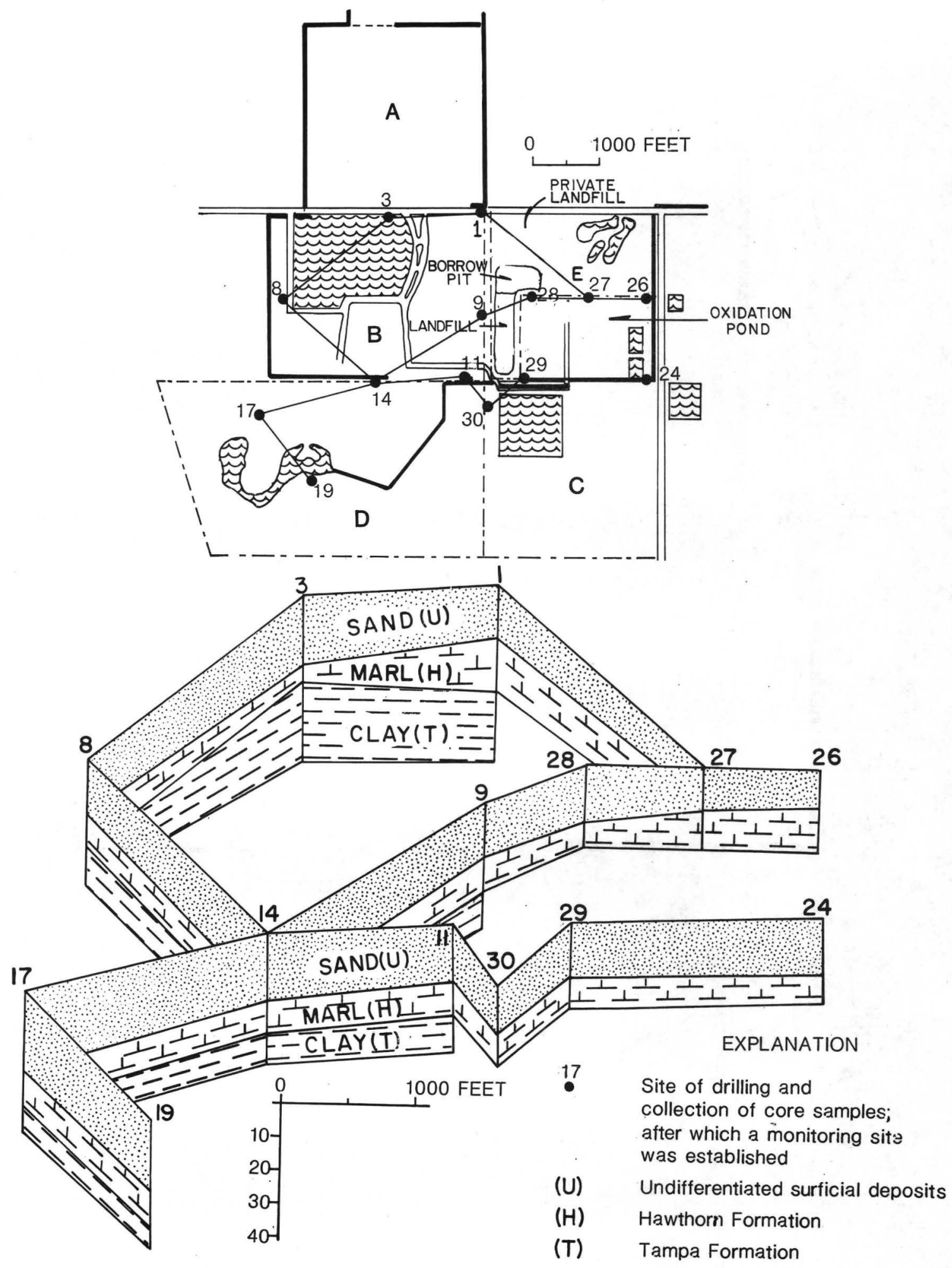

Figure 6.--Index map and geologic fence diagram of Pinellas County landfill study area. 
Table 1.--Relation of geologic formations and geohydrologic units

\begin{tabular}{|c|c|c|c|c|c|}
\hline $\begin{array}{l}\text { Geologic } \\
\text { formation }\end{array}$ & $\begin{array}{l}\text { Geologic } \\
\text { age }\end{array}$ & $\begin{array}{c}\text { Average } \\
\text { depth } \\
\text { below } \\
\text { land } \\
\text { surface } \\
\text { (feet) }\end{array}$ & $\begin{array}{l}\text { Average } \\
\text { thick- } \\
\text { ness } \\
\text { (feet) }\end{array}$ & Lithology & $\begin{array}{l}\text { Geohydro- } \\
\text { logic } \\
\text { unit }\end{array}$ \\
\hline $\begin{array}{l}\text { Undifferen- } \\
\text { tiated sur- } \\
\text { ficial de- } \\
\text { posits. }\end{array}$ & \multirow{4}{*}{$\begin{array}{l}\text { Pleistocene. } \\
\text { Unconformity } \\
\text { Middle } \\
\text { Miocene. } \\
\text { Unconformity } \\
\text { Early } \\
\text { Miocene. }\end{array}$} & & 19 & $\begin{array}{l}\text { Fine sand, clayey } \\
\text { sand, tan to ye1- } \\
\text { lowish brown, she11 } \\
\text { fragments. }\end{array}$ & $\begin{array}{c}\text { Surficial } \\
\text { aquifer. }\end{array}$ \\
\hline $\begin{array}{l}\text { Hawthorn } \\
\text { Formation. }\end{array}$ & & & 10 & $\begin{array}{l}\text { Calcareous clay or } \\
\text { marl, sandy, green- } \\
\text { ish gray. }\end{array}$ & \\
\hline \multirow[t]{2}{*}{$\begin{array}{l}\text { Tampa Lime- } \\
\text { stone. }\end{array}$} & & & 25 & $\begin{array}{l}\text { Stiff clay, dark } \\
\text { green with lime- } \\
\text { stone fragments. }\end{array}$ & \\
\hline & & & 200 & $\begin{array}{l}\text { Hard chert and fos- } \\
\text { siliferous lime- } \\
\text { stone. }\end{array}$ & $\begin{array}{l}\text { Upper part } \\
\text { of Flori- } \\
\text { dan aqui- } \\
\text { fer. }\end{array}$ \\
\hline
\end{tabular}

The following is a generalized description of the deposits penetrated during test drilling:

1. Surficial sand: The surficial sand ranges in thickness from 12 to 25 feet (average 19 feet) and is Pleistocene in age (Heath and Smith, 1954, p. 16). The sand is mostly fine to very fine, subrounded, clear, tan to yellowish brown-black in color, and contains iron oxide grains and shell and pelecypod fragments. The sand is mainly quartz with traces of calcite, aragonite, kaolinite, montmorillinite, and mixed clay minerals.

2. Marl layer: The marl layer ranges in thickness from 5 to 15 feet (average 10 feet) and is a local facies of the Hawthorn Formation of middle Miocene age (Heath and Smith, 1954). The marl is composed of calcareous silt (mainly calcite and aragonite with traces of dolomite and mixed clay minerals) mixed with very fine quartz sand, light greenish-gray in color, and contains black polished and pitted, fine to coarse, rounded lithic fragments, and minor shell, pelecypod, and shark tooth fragments. 
Table 2.--Physical characteristics of selected geologic samples

\begin{tabular}{|c|c|c|c|c|c|c|c|c|c|c|}
\hline \multirow{2}{*}{$\begin{array}{c}\text { We11 } \\
\text { number }\end{array}$} & \multirow{2}{*}{$\begin{array}{l}\text { Test } \\
\text { hole } \\
\text { number }\end{array}$} & \multirow{2}{*}{$\begin{array}{l}\text { Depth } \\
\text { below } \\
\text { land } \\
\text { surface } \\
\text { (feet) }\end{array}$} & \multirow{2}{*}{$\begin{array}{l}\text { Geo- } \\
\text { hydro- } \\
\text { logic/ } \\
\text { unit- }\end{array}$} & \multirow{2}{*}{$\begin{array}{l}\text { Forma } \\
\text { tion }\end{array}$} & \multirow{2}{*}{$\begin{array}{l}\text { Median } \\
\text { grain } \\
\text { size } \\
(\mathrm{mm})\end{array}$} & \multicolumn{2}{|c|}{ Porosity } & \multicolumn{2}{|c|}{$\begin{array}{l}\text { Hydraulic } \\
\text { conductivity }\end{array}$} & \multirow{2}{*}{$\begin{array}{c}\text { Cation } \\
\text { exchange } \\
\text { capacity } \\
\text { C } \\
\text { (meq/g) }\end{array}$} \\
\hline & & & & & & $\begin{array}{l}\text { Total, } \\
\text { in } \\
\text { percent }\end{array}$ & $\begin{array}{c}\text { Effective, } \\
\text { in } \\
\text { percent }\end{array}$ & $\begin{array}{c}\text { Vertical } \\
K \\
(f t y d)\end{array}$ & $\begin{array}{c}\text { Hori- } \\
\text { zontal } \\
K_{(\mathrm{ft} / \mathrm{d})}\end{array}$ & \\
\hline 252120824068 & 11 & $\begin{array}{r}2.0-2.5 \\
8.0-8.5 \\
13.0-13.5 \\
18.0-18.5 \\
23.0-23.5 \\
28.0-28.5 \\
33.0-33.5 \\
38.0-38.5\end{array}$ & $\begin{array}{l}\text { S } \\
\text { S } \\
\text { S } \\
\text { S } \\
\text { C } \\
\text { C } \\
\text { C } \\
\text { C }\end{array}$ & $\begin{array}{l}\mathrm{U} \\
\mathrm{U} \\
\mathrm{U} \\
\mathrm{U} \\
\mathrm{H} \\
\mathrm{T} \\
\mathrm{T} \\
\mathrm{T} .\end{array}$ & $\begin{array}{c}-- \\
-- \\
.16 \\
-- \\
6.3 \times 10^{-3} \\
9.3 \times 10^{-2} \\
-- \\
--\end{array}$ & $\begin{array}{c}-- \\
-- \\
31.1 \\
-- \\
31.5 \\
31.5 \\
-- \\
--\end{array}$ & $\begin{array}{c}-- \\
-- \\
28.6 \\
-- \\
28.8 \\
25.6 \\
-- \\
--\end{array}$ & $\begin{array}{c}-- \\
-- \\
4.73 \times 10^{-5} \\
1.24 \times 10^{-4} \\
1.23 \times 10^{-4} \\
3.28 \times 10^{-4} \\
-- \\
--\end{array}$ & $\begin{array}{c}-- \\
-- \\
-- \\
8.86 \times 10^{-1} \\
-- \\
-- \\
-- \\
--\end{array}$ & $\begin{array}{l}-- \\
-- \\
-- \\
-- \\
4.0 \\
12 \\
41 \\
--\end{array}$ \\
\hline 252120824101 & 14 & $\begin{array}{c}2.0-2.5 \\
8.0-8.5 \\
13.0-13.5 \\
18.0-18.5 \\
23.0-23.5 \\
28.0-28.5 \\
33.0-33.5 \\
38.0-38.5\end{array}$ & $\begin{array}{l}\text { S } \\
\text { S } \\
\text { S } \\
\text { S } \\
\text { C } \\
\text { C } \\
\text { C } \\
\text { C }\end{array}$ & $\begin{array}{l}\mathrm{U} \\
\mathrm{U} \\
\mathrm{U} \\
\mathrm{U} \\
\mathrm{H} \\
\mathrm{H} \\
\mathrm{T} \\
\mathrm{T}\end{array}$ & $\begin{array}{c}.17 \\
.14 \\
.12 \\
.12-3 \\
6.2 \times 10^{-3} \\
6.6 \times 10^{-2} \\
-- \\
--\end{array}$ & $\begin{array}{c}35.8 \\
31.7 \\
32.6 \\
-- \\
39.9 \\
32.2 \\
37.2 \\
48.7\end{array}$ & $\begin{array}{c}32.9 \\
27.1 \\
29.6 \\
-- \\
37.3 \\
27.9 \\
10.2 \\
23.5\end{array}$ & $\begin{array}{c}1.44 \times 10^{-3} \\
-- \\
-- \\
9.84 \times 10^{-5} \\
1.88 \times 10^{-4} \\
1.87 \times 10^{-4} \\
4.99 \times 10^{-5} \\
--\end{array}$ & $\begin{array}{l}3.28 \\
-- \\
-- \\
-- \\
-- \\
-- \\
-- \\
--\end{array}$ & $\begin{array}{l}.5 \\
3.4 \\
3.1 \\
7.7 \\
2.8 \\
3.6 \\
25 \\
38\end{array}$ \\
\hline 2752030824014 & SF63 & $42.0-42.5$ & $\mathrm{C}$ & $\mathrm{T}$ & -- & 33.0 & 19.0 & $1.08 \times 10^{-4}$ & -- & -- \\
\hline
\end{tabular}

$\underline{1}$ Geohydrologic units: S, surficial aquifer; C, confining bed.

2/ Formation: U, undifferentiated surficial deposits; H, Hawthorn Formation; T, Tampa Limestone.

$\underline{3} /$ Test hole located about 2,500 feet southeast of Pinellas County landfill. 
3. Clay layer: The clay layer is probably a weathered residuum of the upper part of the Tampa Limestone (Hutchinson and Stewart, 1978). The clay layer is estimated to be about 25 feet in thickness at most places. The clay contains fine to very fine, white quartz grains with phosphate nodules and limestone fragments and is light greenish-gray to grayish-blue-green in color. Mixed clay minerals, quartz, illite, and cristobalite are present in the clay.

4. Limestone layer: Limestone of the Tampa Limestone was penetrated in the test holes drilled at the St. Petersburg Toytown landfill and at the Carpet well near the study area (fig. 7). The limestone is estimated to be about 200 feet thick in Pinellas County (Hickey, 1980). The limestone is cream colored, chalky, sandy, fossiliferous, with chert decreasing with depth. A 57-foot test hole that was drilled in the study area penetrated the clay layer and an underlying clay, limestone fragments, and chert zone.

\section{HYDROGEOLOGY}

\section{Geohydrologic Units}

Three geohydrologic units comprise the deposits that underlie the study area (table 1 and fig. 7). These units are, in descending order: (1) surficial aquifer--an unconfined permeable sand layer of fine to very fine sand and she11; (2) confining bed--a semipermeable layer of marl and clay; and (3) Floridan aquifer--a confined or artesian limestone aquifer. The permeable sand layer averages 19 feet in thickness and both its saturated and unsaturated portions comprise the surficial aquifer (table 1 ). The marl and clay confining bed separates the surficial aquifer from the Floridan aquifer and averages 35 feet in thickness. The upper 5 feet of the confining layer is excavated for fill and cover material during the landfilling operations. The Floridan aquifer is the principal aquifer in the area (Hutchinson and Stewart, 1978). The freshwater strata of the upper part of the Floridan aquifer are estimated to be about 200 feet thick (Hickey, 1980).

\section{Water Levels}

A total of 38 test wells finished in the surficial aquifer and 22 surfacewater sites were used to determine the direction of ground-water movement in the surficial aquifer. Water-table altitudes of the surficial aquifer for May and September 1977 are presented in figure 8.

The following summarizes the average water levels in the surficial aquifer at the study site during 1977:

\begin{tabular}{lcccc} 
Season & Month & $\begin{array}{c}\text { Average depth to water in } \\
\text { feet below land surface }\end{array}$ & $\begin{array}{c}\text { Altitude of average } \\
\text { water table in feet } \\
\text { above sea level }\end{array}$ \\
\cline { 3 - 3 } Dry & May & 5 & 5 & 5
\end{tabular}




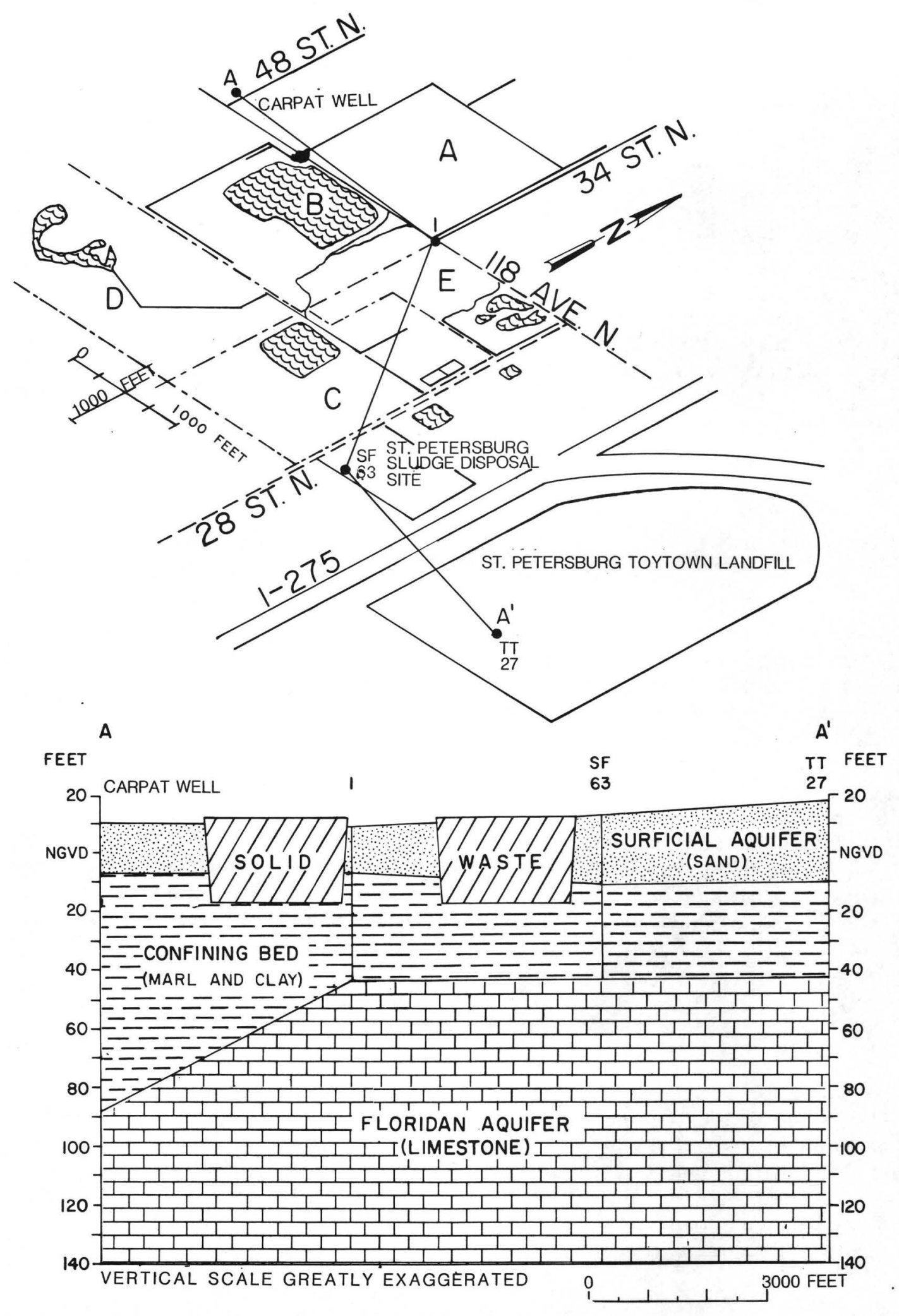

Figure 7.--Generalized hydrogeologic section at the landfill. 


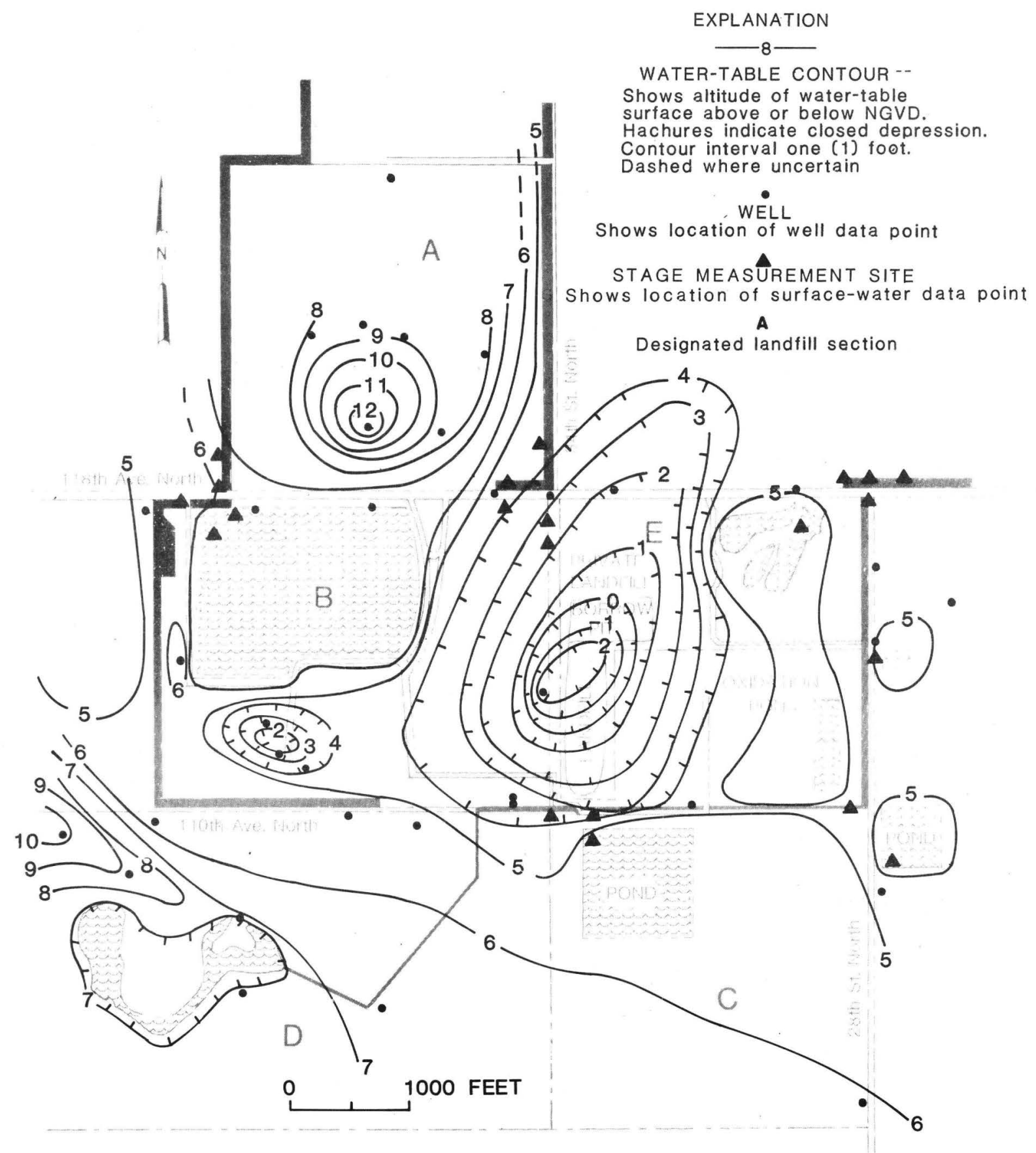

Figure 8a.--Water-level altitudes in the surficial aquifer, May 1977. 


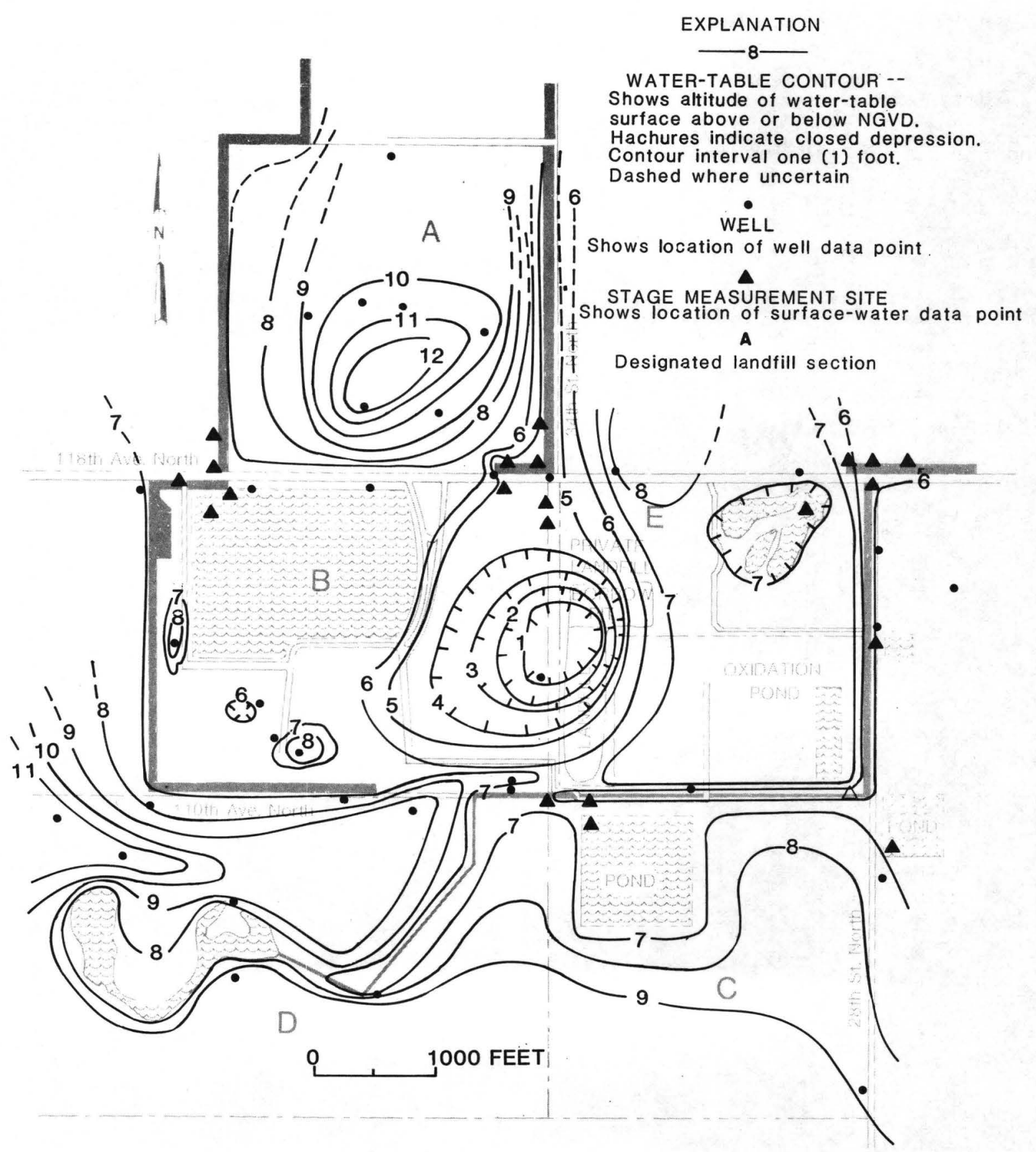

Figure 8b.--Water-level altitudes in the surficial aquifer, September 1977. 
The potentiometric surface of the Floridan aquifer was about 4 feet above sea level in May 1977 and 7 feet above it in September 1977 based on measurements in an observation well about 1 mile south of the study area.

As shown in figure 8, a water-table mound reaching an altitude of more than 12 feet above sea level occurred in section A where the surficial aquifer had been replaced by less permeable solid-waste fill. Water from the filled trenches and the relatively low permeability of the fill caused the water-table mound. At a privately owned landfill bordering the northwest boundary of section C on 34 th Street North, a cone of depression in the water table occurred because of dewatering operations at a borrow pit (fig. 5) within the section.

The May and September water-level maps are similar, except that the water levels have risen, in general, from May to September as a result of the summer rainy season. The cones of depression in the southern and eastern part of section B are wider and deeper in May. However, the general pattern of both maps remains the same, with a water-table mound in both the north and southwest parts of the study area. A new mound appeared in the northeast part of the area in September. In general, decline of the water table is rather uniform, although mounds in section $A$ and northwest of section $D$ are about the same maximum altitudes in September and May.

\section{GROUND-WATER MOVEMENT}

Local changes in ground-water quality in the surficial and Floridan aquifers as a result of landfill operations are dependent on the rate and direction of movement of leachate, both vertical and horizontal. Some physical factors affecting movement of leachate are the horizontal and vertical hydraulic conductivity and effective porosity of the geologic materials and the hydraulic gradient in and head differences between the confined and unconfined aquifers.

In most cases, a leachate will move through an aquifer at a slower rate than ground water. The leachate tends to undergo chemical reactions and is absorbed in or adsorbed on the material through which it passes, all of which tend to slow the rate of movement of the leachate relative to ground water. An exception would be where the leachate is a conservative ion, such as chloride that does not readily react chemically nor is it absorbed or adsorbed. A conservative ion will move at the same rate as the ground water it is in.

The following discussions are related to the movement of ground water, not leachate. Thus, the estimates presented with regard to the rate of movement of most leachates can be considered conservative.

\section{Horizontal Movement}

The regional direction of horizontal ground-water movement is northeasterly toward 0ld Tampa Bay (fig. 9). The regional ground-water flow map is based, in part, on the assumption that ground-water flow is a subdued reflection of the general topography. The velocity of ground-water flow through the surficial (unconfined) aquifer toward 0ld Tampa Bay can be calculated using a modified form of Darcy's equation: 


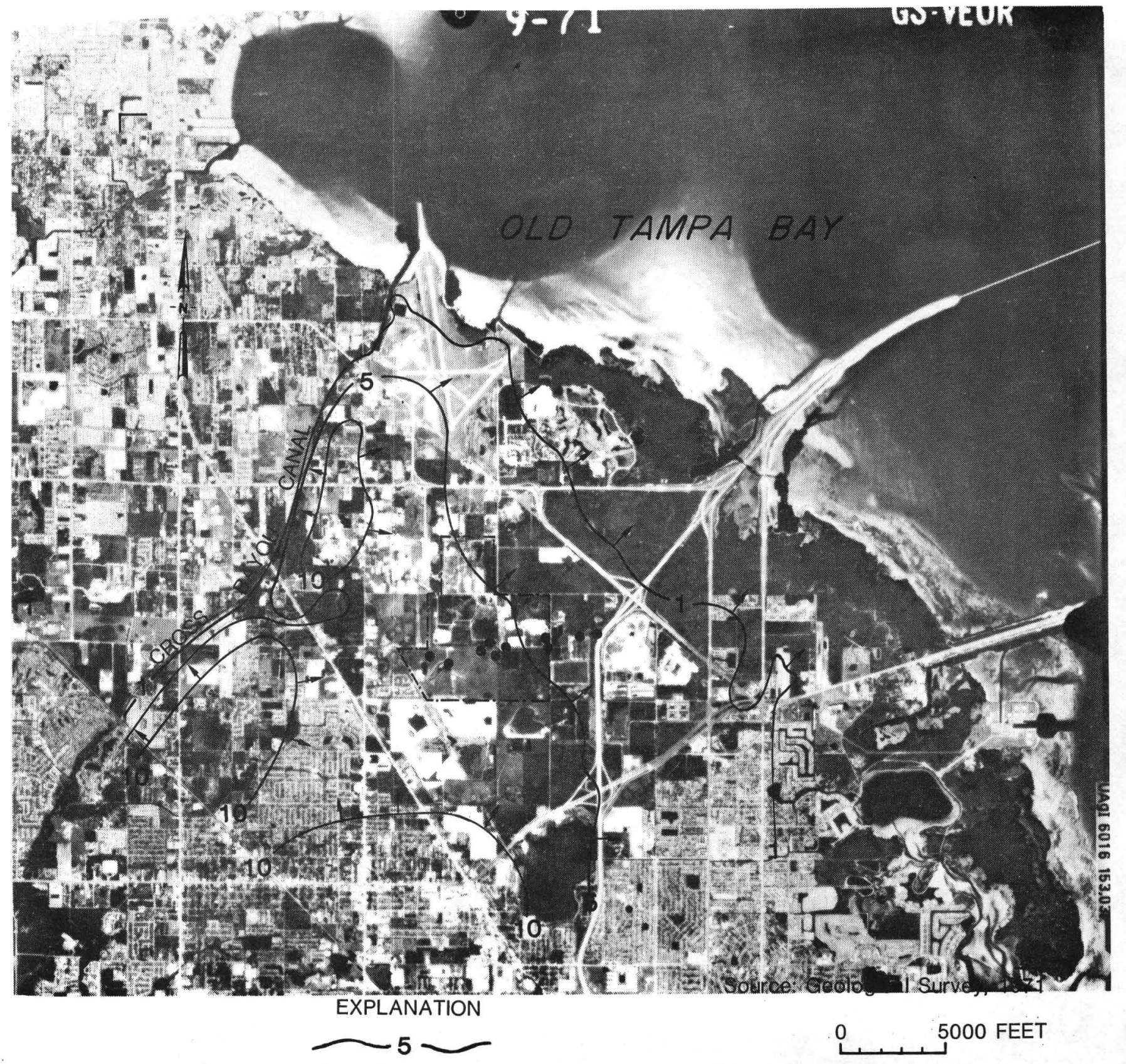

WATER-TABLE CONTOUR--Shows generalized

altitude of water-table surface estimated

from altitude of land surface above NGVD.

Contour interval 1,4 , and 5 feet

$\longrightarrow$ Direction of ground-water flow

-.-.- Boundary of study area

- Ground-water data point

Figure 9.--Generalized regional configuration of the water level in the surficial aquifer showing direction of ground-water movement. 


$$
\mathrm{V}_{\mathrm{h}}=\mathrm{K}_{\mathrm{h}} \mathrm{I} / \mathrm{n}_{\mathrm{e}}
$$

where: $V_{h}=$ horizontal velocity, in feet per day;

$\mathrm{K}_{\mathrm{h}}=$ horizontal hydraulic conductivity, in feet per day;

$I$ = hydraulic gradient, in feet per foot;

$\mathrm{n}_{\mathrm{e}}=$ effective porosity, dimensionless.

The calculations assume that the average hydraulic conductivity of $2.1 \mathrm{ft} / \mathrm{d}$ is representative of the surficial aquifer based on determinations from two samples, 3.28 and $0.886 \mathrm{ft} / \mathrm{d}$ (table 2), from the upper and lower part of the surficial sand. A value of $1.2 \mathrm{ft} / \mathrm{d}$ for horizontal hydraulic conductivity has been reported for sand of the surficial aquifer about 1 mile east of the Pinellas County landfill (Hutchinson and Stewart, 1978, p. 14).

The regional hydraulic gradient, $4.5 \times 10^{-4} \mathrm{ft} / \mathrm{ft}$, was based on water levels from wells (fig. 9) measured during September 1972 and was computed using an arc cosine graphical solution as described by Rorabaugh (1960, p. 314-323). It was assumed that the approximate average effective porosity, $n_{e}=0.3$, of the undifferentiated surficial deposits (table 2) is representative of the region. The calculated rate for the regional horizontal movement of water in the surficial aquifer to Old Tampa Bay under natural conditions is as follows:

$$
\begin{aligned}
& V_{h}=\frac{(2.1 \mathrm{ft} / \mathrm{d})\left(4.5 \times 10^{-4} \mathrm{ft} / \mathrm{ft}\right)}{0.3} \\
& V_{h}=3.2 \times 10^{-3} \mathrm{ft} / \mathrm{d} .
\end{aligned}
$$

This rate of water movement is equivalent to about $1.2 \mathrm{ft} / \mathrm{yr}$. In their report on the Toytown landfill, which is located about 1 mile east of the study site (fig. 2), Hutchinson and Stewart (1978) report a rate of horizontal movement of $1 \mathrm{ft} / \mathrm{yr}$. At a rate of $1.2 \mathrm{ft} / \mathrm{yr}$, it would take about 11,000 years for water to travel from the landfill area to Old Tampa Bay.

\section{Vertical Movement}

The marl and clay confining bed at the study site retards downward movement of ground water from the overlying surficial aquifer to the Floridan aquifer. To determine the rate of vertical migration from the surficial aquifer through the confining bed, the following modified form of Darcy's equation was used:

$$
V=\frac{\mathrm{K}_{\mathrm{v}} \mathrm{h}}{\mathrm{BN}_{\mathrm{e}}}
$$

where: $\mathrm{K}_{\mathrm{v}}=$ composite coefficient of vertical hydraulic conductivity of confining layer, in feet per day;

$B=$ thickness of confining bed, in feet; 


$$
\begin{aligned}
& \mathrm{h}=\text { head difference between the surficial and Floridan aquifers, } \\
& \text { in feet; } \\
& \mathrm{N}_{\mathrm{e}}=\begin{array}{c}
\text { composite coefficient of effective porosity of confining layer, } \\
\text { dimensionless. }
\end{array}
\end{aligned}
$$

The composite coefficient of vertical hydraulic conductivity (modified from De Wiest, 1965, p. 231), as used to determine the net effect of the geologic deposits in retarding the downward migration, was determined by the following equation:

$$
\mathrm{k}_{\mathrm{v}}=\frac{\mathrm{B}}{\mathrm{b}_{1} / \mathrm{k}_{1}+\mathrm{b}_{2} / \mathrm{k}_{2}+\ldots \mathrm{b}_{\mathrm{n}} / \mathrm{k}_{\mathrm{n}}}
$$

where: $\mathrm{K}_{\mathrm{v}}=$ composite coefficient of vertical hydraulic conductivity, in feet per day;

$B=$ thickness of confining bed, in feet;

$\mathrm{b}_{\mathrm{n}}=$ thickness of each layer within confining bed, in feet;

$k_{n}=$ coefficient of vertical hydraulic conductivity of each layer.

Where more than one vertical hydraulic conductivity was determined for a reported depth (table 2), an average was used. A vertical column showing sediments and the corresponding values of vertical hydraulic conductivity and effective porosity are presented in figure 10 .

Substituting values from figure 10 into equation 3, the composite coefficient of vertical permeability, $\mathrm{K}_{\mathrm{v}}$, is $9.6 \times 10^{-5} \mathrm{ft} / \mathrm{d}$. The calculation assumes the confining bed averages 35 feet in thickness, including 10 feet of marl and 25 feet of clay. The vertical hydraulic conductivity for clay at a depth of 42 feet $\left(1.08 \times 10^{-4} \mathrm{ft} / \mathrm{d}\right)$ was used in calculating the $\frac{(\mathrm{b})}{\mathrm{k}}$ for the bottom 12 feet of clay.

The composite coefficient of effective porosity for the confining bed, $\mathrm{N}_{\mathrm{e}}$, was calculated using the same equation 3 for $\mathrm{K}_{v}$, except that values for $\mathrm{n}_{\mathrm{e}}$ were substituted for $\mathrm{k}_{\mathrm{v}}$ :

$$
\mathrm{N}_{\mathrm{e}}=\frac{\mathrm{B}}{\mathrm{b}_{1} / \mathrm{n}_{\mathrm{e}_{1}}+\mathrm{b}_{2} / \mathrm{n}_{\mathrm{e}_{2}}+\ldots \mathrm{b}_{\mathrm{n}} / \mathrm{n}_{\mathrm{e}_{\mathrm{n}}}}
$$

Substituting the values from figure 10 into equation 4, the composite coefficient of effective porosity, $\mathrm{N}_{e}$, is 0.19 .

Substituting the above values for $\mathrm{K}_{\mathrm{v}}\left(9.6 \times 10^{-5} \mathrm{ft} / \mathrm{d}\right)$ and $\mathrm{N}_{\mathrm{e}}(0.19)$ into equation 2 and assuming that (1) the average thickness of the confining bed is 35 feet and (2) the head difference between the surficial aquifer and the Floridan aquifer is 1 foot, gives results as follows:

$$
\begin{aligned}
& V=\frac{\left(9.6 \times 10^{-5} \mathrm{ft} / \mathrm{d}\right)(1 \mathrm{ft})}{(35 \mathrm{ft})(0.19)} \\
& V=1.4 \times 10^{-5} \mathrm{ft} / \mathrm{d} .
\end{aligned}
$$


FEET

BELOW

LAND

SURFACE COLUMN
VERTICAL

HYDRAULIC EFFECTIVE

CONDUCTIVITY POROSITY

(AV. FT./D)

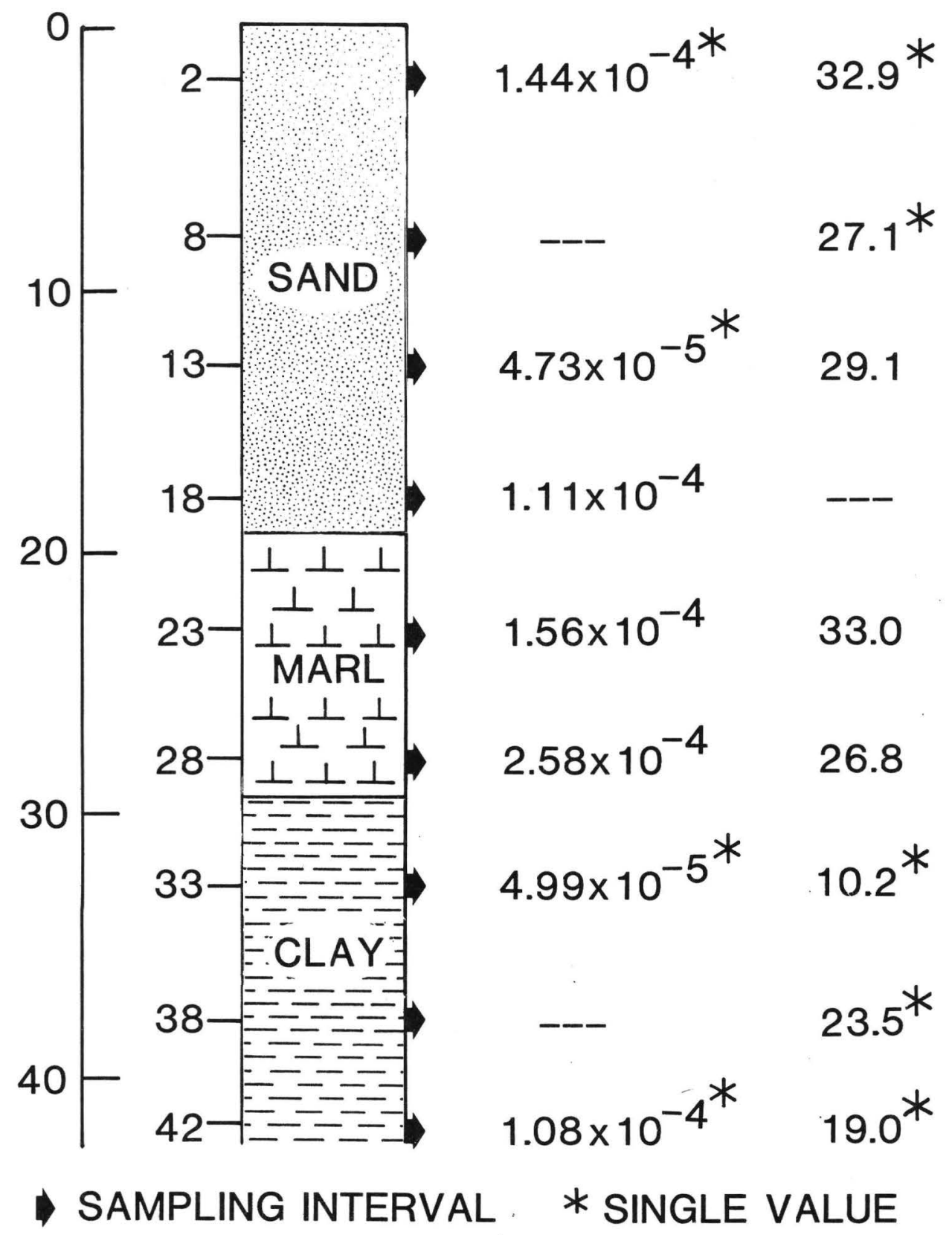

Figure 10.--Generalized geologic column showing thickness of each layer and corresponding hydraulic conductivity and effective porosity. 
The calculated rate of vertical movement of ground water is $5.1 \times 10^{-3} \mathrm{ft} / \mathrm{yr}$. Thus, at this calculated rate, the ground water would take about 7,000 years to move through the full thickness of the confining layer (fig. 11). If the top 10 feet of confining layer were removed for trench excavation, the rate of vertical movement of ground water would be $7.9 \times 10^{-3} \mathrm{ft} / \mathrm{yr}$, and it would take about 3,000 years for the ground water to move through the confining layer. These calculated rates of vertical migration are based on the assumption that the confining layer is persistent throughout the landfill area. In any of the above time spans, the chemical quality of a leachate moving with the ground water would most likely be drastically changed in character by the time it reached the Floridan aquifer.

\section{WATER QUALITY}

The effects of landfill operations on water quality were evaluated using data on the quality of water obtained from ground- and surface-water sites outside the landfill operation as reference standards. These results were then compared with water-quality results from sites within the landfill area. The quality of water for a Floridan aquifer well at section A was compared to water from Floridan aquifer wells about 10 miles west of the site that are open to the same water-bearing zones. All sites, except for the Floridan aquifer background wells, were sampled for nutrients, COD, major cations, and trace metals. Locations of background sampling sites for the surficial aquifer and surfacewater bodies near the landfill are shown in figure 12. All the wells tapping the aquifers and surface-water sites were sampled on a periodic basis for background quality information and landfill site information. Wells were sampled three times if in landfill trenches that were 5 or more years old, and open trenches in the process of being filled were sampled four times for fresh leachate.

Parameters analyzed to establish background water-quality data for surface and ground water and recommended standards established by the U.S. Environmental Protection Agency and the State of Florida Department of Environmental Regulation are shown in table 3. The data include the mean and, if sufficient data were obtained, the standard deviation. These data are presented in tables and illustrations in the form $1,280 \pm 550$, where the first number is the mean and the second number is the standard deviation. The minimum and maximum observed values for the respective parameters are also presented next to the mean and standard deviation values. Data indicate that background levels for all parameters tested, except ammonia nitrogen, are below U.S. Environmental Protection Agency (1976a) maximum recommended limits. However, total chromium exceeds Florida Department of Environmental Regulation (1978) recommended limits.

New leachate (from trenches less than 1 year old) has lower specific conductance than old leachate (from trenches more than 5 years old) because a breakdown of the degradable waste has only begun. Nitrogen in the organic form is higher in new leachate due to organic nitrogen not yet being converted to ammonia. Ammonia increases with time, as shown in the high levels of ammonia nitrogen (240-400 $\mathrm{mg} / \mathrm{L})$ in the old leachate compared to the low levels in the new leachate $(0.05-1.7 \mathrm{mg} / \mathrm{L})$. High COD values in new leachate $(0-1,100 \mathrm{mg} / \mathrm{L})$ water is the result of organic matter in the garbage. Relatively high zinc levels, although still lower than U.S. Environmental Protection Agency recommended limits, probably derive from galvanized metal products in the solid waste. 


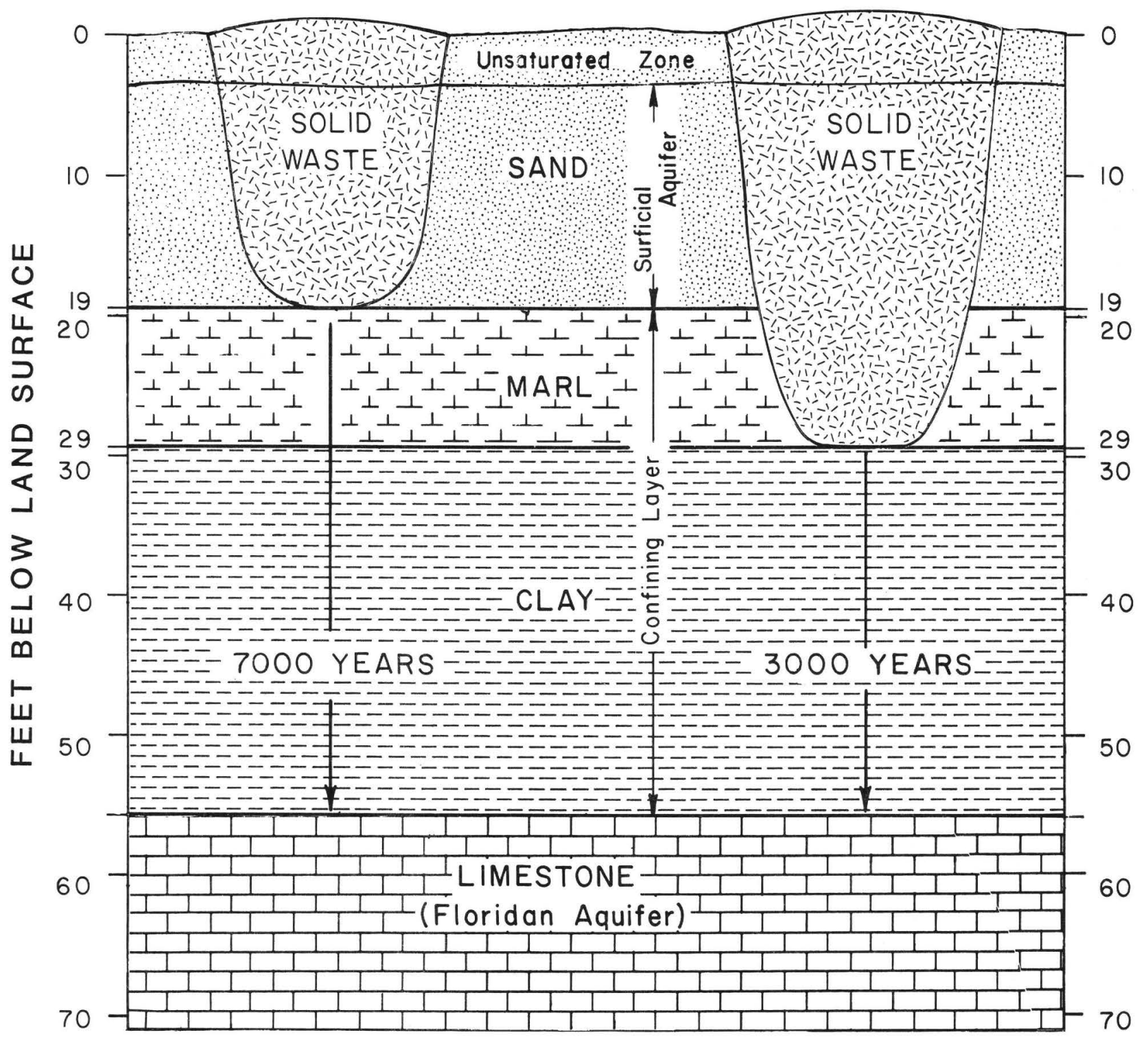

Figure 11.--Generalized geologic section showing time required for contaminants to migrate vertically from landfill trenches to the Floridan aquifer. 
Table 3.--Background and trench water

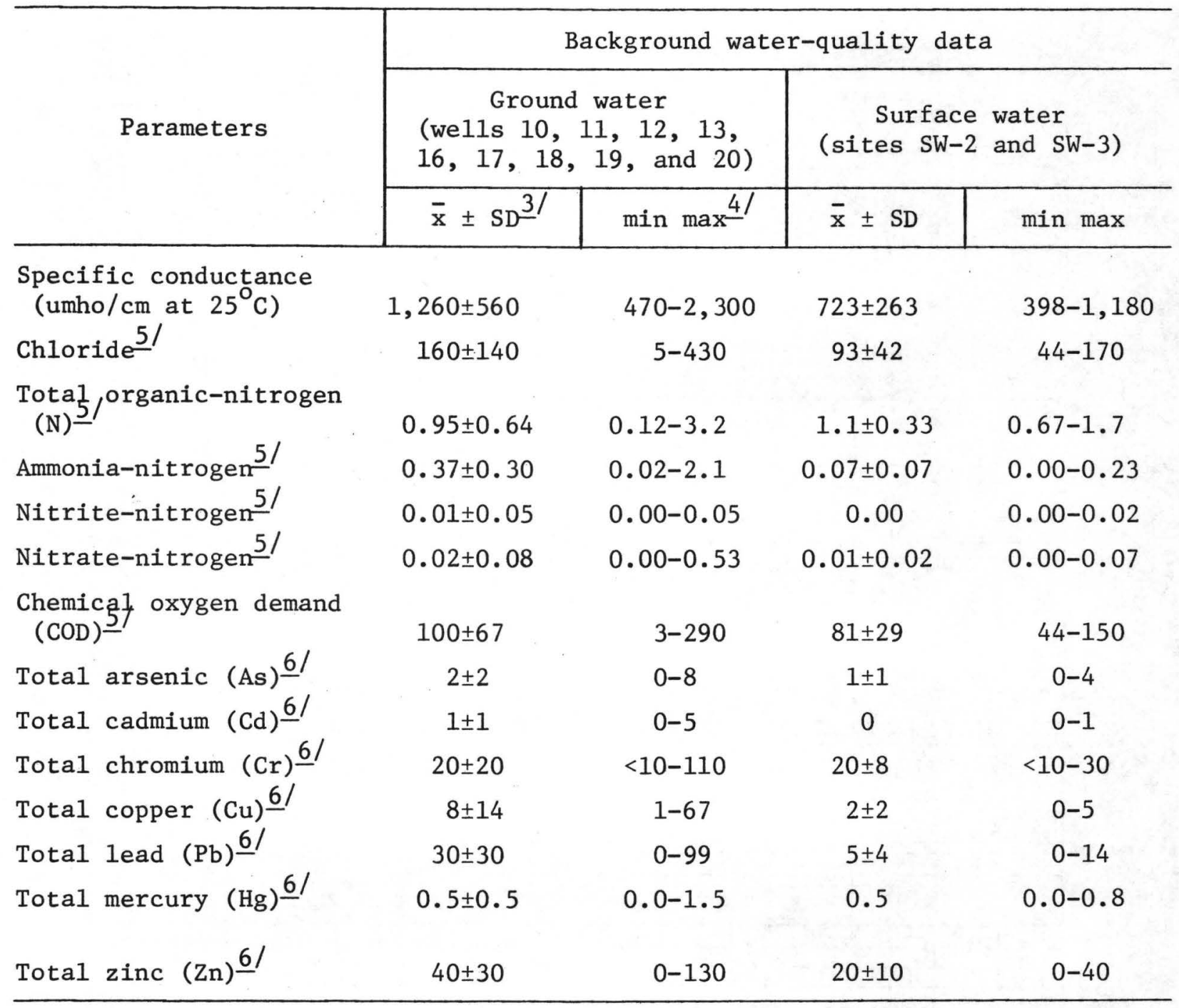

1/ U.S. Environmental Protection Agency, 1976a. Concentrations of water constituents which, if not exceeded, are expected to result in an aquatic ecosystem suitable for the higher uses of water. Dashed where no standards have been established.

2/ Florida Department of Environmental Regulation, 1978. Concentrations that shall not be exceeded. Dashed where no standards have been established.

3/ The first figure shown is the mean, the second figure is the standard deviation. 


\begin{tabular}{|c|c|c|c|c|c|}
\hline \multicolumn{4}{|c|}{$\begin{array}{l}\text { Trench water } \\
\text { (leachate) }\end{array}$} & \multirow{2}{*}{\multicolumn{2}{|c|}{$\begin{array}{l}\text { Recommended } \\
\text { standards }\end{array}$}} \\
\hline \multicolumn{2}{|c|}{$\begin{array}{c}01 \mathrm{~d}^{7 /} \\
\text { (sites } 5 \text { and } 5 \mathrm{C} \text { ) }\end{array}$} & \multicolumn{2}{|c|}{$\begin{array}{cl}\text { New } \\
\text { (open trenches) }\end{array}$} & & \\
\hline $\bar{x}$ & $\min \max$ & $\bar{x}$ & $\min \max$ & E.P.A. $1 /$ & D.E.R. $\frac{2 /}{}$ \\
\hline 4,370 & $2,820-5,590$ & 1,750 & $1,010-3,550$ & -- & -- \\
\hline 420 & $370-480$ & 110 & $74-130$ & -- & -- \\
\hline 7.3 & $4-9.2$ & 9.3 & $0.72-16$ & -- & -- \\
\hline 340 & $240-400$ & 0.81 & $0.05-1.7$ & 0.02 & -- \\
\hline 0.05 & $0.02-0.07$ & 0.02 & $0.01-0.04$ & 10 & -- \\
\hline 0.05 & $0.00-0.14$ & 0.21 & $0.00-0.80$ & 10 & 10 \\
\hline 540 & $500-570$ & 380 & $0-1,100$ & -- & -- \\
\hline 2 & $1-4$ & 20 & $4-61$ & 50 & 5 \\
\hline 0 & $0-0$ & 2 & $0-4$ & 10 & 10 \\
\hline 40 & $30-60$ & 140 & $20-350$ & 50 & 5 \\
\hline 13 & $6-20$ & 20 & $1-66$ & 1,000 & -- \\
\hline 24 & $6-40$ & 30 & $2-97$ & 50 & 50 \\
\hline $\begin{array}{r}0.5 \\
\text { or 1ess }\end{array}$ & $<0.5-0.8$ & 0.5 & $0-1.0$ & 2 & 2 \\
\hline 70 & $20-150$ & 250 & $11-790$ & 5,000 & -- \\
\hline
\end{tabular}

4/ The first figure shown is the minimum value, the second figure is the maximum value.

5/ Concentration in milligrams per liter.

6/ Concentration in micrograms per liter.

I/ Trench more than 5 years old. 


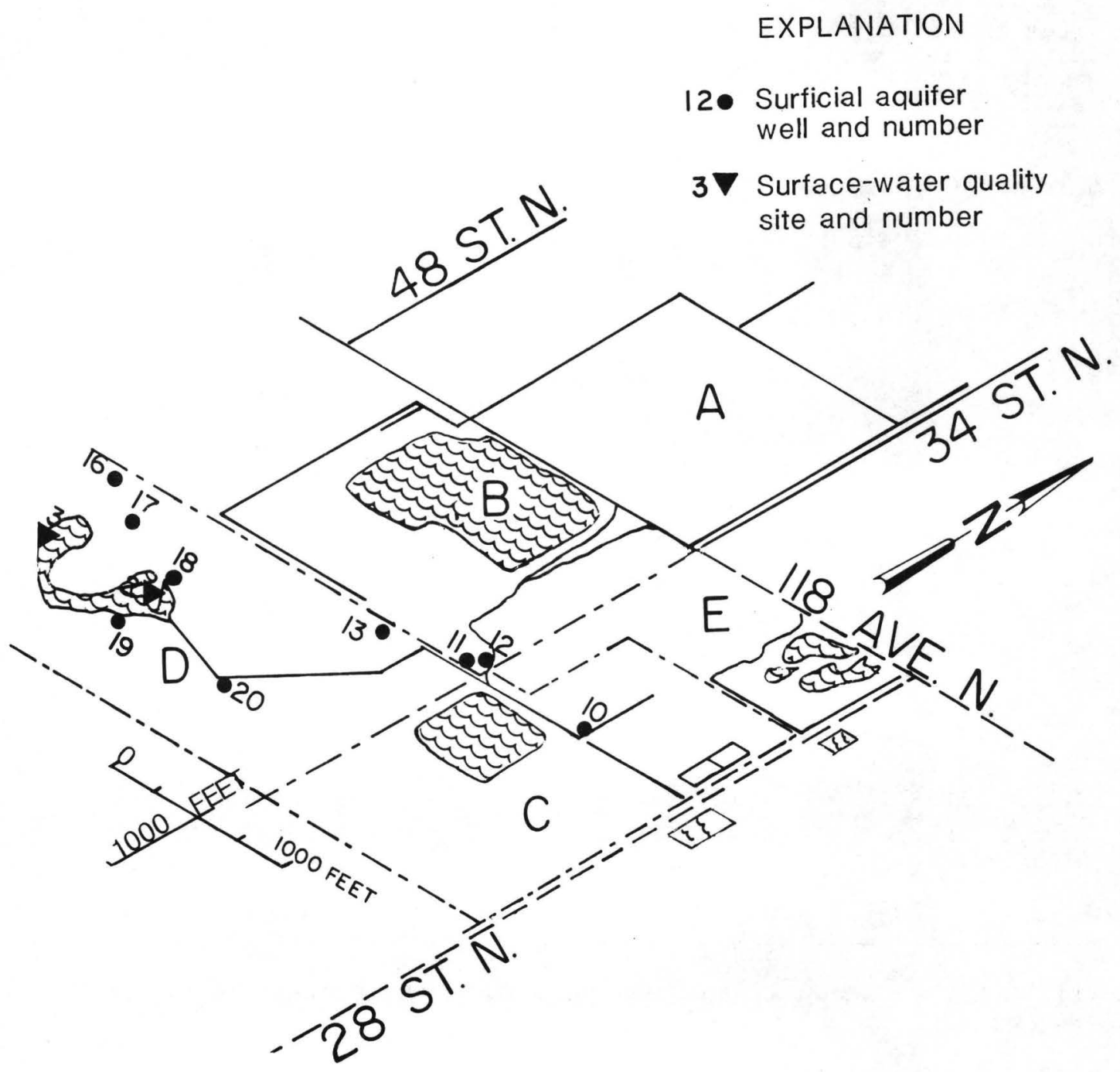

Figure 12.--Location of ground-water and surface-water quality sampling sites. 


\section{Effects of Leachate on Water Quality}

Five parameters were selected for use in illustrating trends in groundand surface-water quality that are caused by landfill operations. The parameters, representative of the physical and chemical character, both organic and inorganic, of leachate, are as follows:

Specific Conductance: The specific conductance of water can be used to estimate the dissolved-solids concentration.

Chloride: The chloride ion is a major constituent in leachate and is considered a tracer due to its inertness (U.S. Environmental Protection Agency, 1975).

Total Organic Nitrogen: Total organic nitrogen is a major constituent in leachate and is a precursor of ammonia nitrogen.

Ammonia Nitrogen: The ammonia-nitrogen species is a major constituent in leachate. 01d leachate water has high levels of ammonia nitrogen due to the degradation of organic nitrogen. Ammnoia nitrogen decreases with age of leachate waters if nitrification occurs (U.S. Environmental Protection Agency, 1975).

Chemical Oxygen Demand: Chemical oxygen demand (COD) is a measure of the chemically oxidizable matter in leachate and is expressed as the oxygen equivalent of oxidizable organic matter (U.S. Environmental Protection Agency, 1975).

\section{Surface-Water Sites}

Surface-water sampling sites SW-1 and SW-4, located in area D (fig. 5), were sampled to detect movement of leachate from the landfill trenches into the ditch on the west and south boundaries of area B. Concentrations of chemical constituents analyzed (Fernandez, 1979) were within or below the range of background concentrations, indicating that alteration of surface water in the ditches as a result of landfill operations had not occurred. However, concentrations of organic and ammonia nitrogen were erratic. The erratic trend was probably due to (1) droppings of seagulls that roost on a berm that borders the landfill trenches along the north side of the ditch and (2) location of the sampling sites near the end of the ditch, which is a stagnant collection point for surface runoff and debris.

\section{Floridan Aquifer}

A sample of ground water from the upper part of the Floridan aquifer underlying the landfill from well $5 \mathrm{bl}$ (fig. 5) was compared with ground water obtained from wells S2, S3, and S4 completed in the same strata about 10 miles to the west (table 4). Analyses of water from well $5 \mathrm{bl}$ indicated that, except for concentrations of potassium, calcium, and ammonia nitrogen, chemical constituents tested, for which comparative data are available, were about the same as or less than concentration values reported for wells S2, S3, and S4. The similarity in water quality between water from well $5 \mathrm{~b} 1$ and water from the wells to the west suggests that downward migration of leachate has not occurred through the confining bed or the annular space outside the well casing into the Floridan aquifer. 
Table 4.--Comparison of water-quality data for a Floridan aquifer we11 (5b1) located within the landfill to water-quality data for wells (S2, S3, S4) completed in the same strata 10 miles west of the landfill

\begin{tabular}{|c|c|c|c|c|c|c|c|c|c|c|c|}
\hline $\begin{array}{c}\text { We11 } \\
\text { number }\end{array}$ & 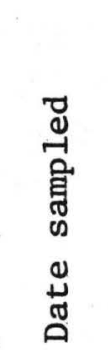 & 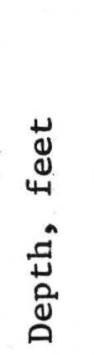 & 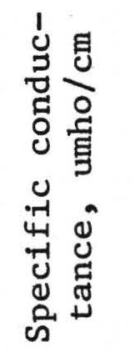 & 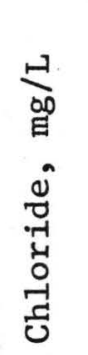 & 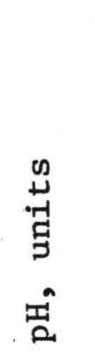 & 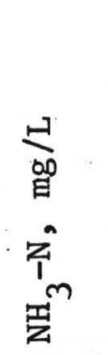 & 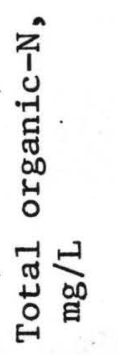 & $\begin{array}{l}\frac{1}{60} \\
\xi \\
z_{1}^{n} \\
0^{n}\end{array}$ & 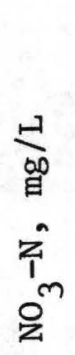 & 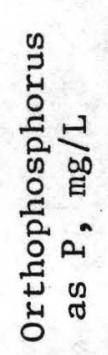 & 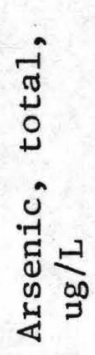 \\
\hline $5 \mathrm{bl}$ & $6 / 77$ & 160 & 1,480 & 210 & 7.0 & 1.0 & 0.1 & 0 & 0 & 0.4 & 1 \\
\hline $\mathrm{s} 2$ & $2 / 74$ & 120 & 262 & 16 & - & - & - & - & - & - & - \\
\hline S3 & $3 / 74$ & 150 & 739 & 94 & 7.3 & .31 & .24 & - & - & - & - \\
\hline S4 & $3 / 74$ & 200 & 1,600 & 380 & 7.1 & .51 & .16 & - & - & - & - \\
\hline
\end{tabular}

\begin{tabular}{|c|c|c|c|c|c|c|c|c|c|c|}
\hline $\begin{array}{c}\text { We11 } \\
\text { number }\end{array}$ & 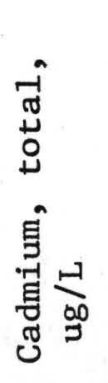 & 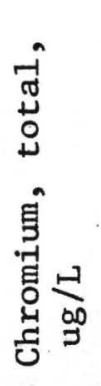 & 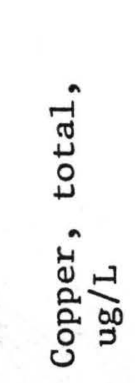 & 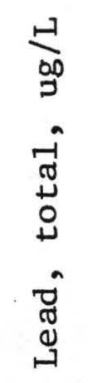 & 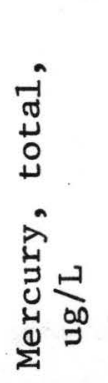 & 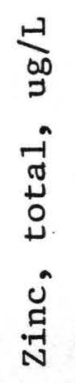 & 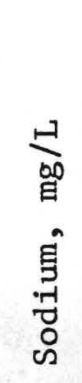 & 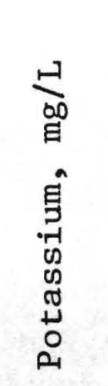 & 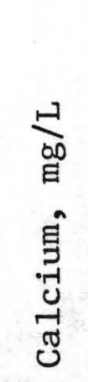 & 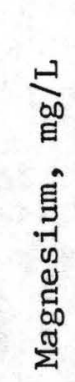 \\
\hline $5 \mathrm{bl}$ & 0 & $<10$ & 4 & 0.5 & 0.5 & 40 & 90 & 4.7 & 160 & 22 \\
\hline $\mathrm{S} 2$ & - & - & - & - & - & - & - & - & - & - \\
\hline S3 & - & - & - & - & - & - & 33 & .16 & 30 & 69 \\
\hline S4 & - & - & - & - & - & - & 110 & 3.3 & 49 & 130 \\
\hline
\end{tabular}

Surficial Aquifer

Leachate movement was not detected in wells sampled in sections B or C; however, there was movement found in section A, based on water-quality sampling. A line of wells (numbers 1, 2, 3, 4, and 7) was drilled into the surficial aquifer along 118th Avenue North to monitor lateral migration of leachate southward from section A (fig. 5). Landfill operations in section A ceased in November 1975, about a year after the monitoring system was installed. Water-quality data from the monitor wells indicate that leachate is moving away from the landfill. Migration of leachate had already started when the study was initiated. 
Wells 2 and 3 showed the greatest increase over background levels in all parameters, whereas wells 1,4 , and 7 remained within or just above background conditions, suggesting that the leachate front is between wells 1 and 4. A summary of findings of selected parameters for water from wells 2, 3, and new trenches are presented in table 5.

Table 5.--Statistics of selected parameters for water from selected wells and old and new trenches

\begin{tabular}{|c|c|c|c|c|}
\hline \multirow{2}{*}{ Parameter } & \multirow{2}{*}{ Wel1 21/ } & \multirow{2}{*}{ Well 3 I/ } & \multicolumn{2}{|c|}{ Trench water } \\
\hline & & & $01 d \underline{2}$ & New $3 /$ \\
\hline $\begin{array}{l}\text { Specific conduc- } \\
\text { tance, umho/cm } \\
\text { at } 25^{\circ} \mathrm{C}\end{array}$ & $\begin{array}{c}4,880 \pm 1,640 \\
(3,360-7,490)\end{array}$ & $\begin{array}{c}6,400 \pm 1,480 \\
(3,900-7,800)\end{array}$ & $\begin{array}{c}4,370 \\
(2,820-4,660)\end{array}$ & $\begin{array}{c}1,750 \\
(1,010-3,550)\end{array}$ \\
\hline Chloride, mg/L & $\begin{array}{c}560 \pm 200 \\
(370-940)\end{array}$ & $\begin{array}{c}820 \pm 170 \\
(580-960)\end{array}$ & $\begin{array}{c}420 \\
(370-480)\end{array}$ & $\begin{array}{c}110 \\
(74-130)\end{array}$ \\
\hline $\begin{array}{l}\text { Total organic } \\
\text { nitrogen, mg/L }\end{array}$ & $\begin{array}{l}22 \pm 9 \\
(9-32)\end{array}$ & $\begin{array}{r}8.8 \pm 7.8 \\
(0.00-17)\end{array}$ & $\begin{array}{c}7.3 \\
(4-9.2)\end{array}$ & $\begin{array}{c}9.4 \\
(0.72-16)\end{array}$ \\
\hline $\begin{array}{l}\text { Ammonia nitrogen, } \\
\mathrm{mg} / \mathrm{L}\end{array}$ & $\begin{array}{l}220 \pm 120 \\
(51-360)\end{array}$ & $\begin{array}{c}360 \pm 82 \\
(200-430)\end{array}$ & $\begin{array}{c}340 \\
(240-400)\end{array}$ & $\begin{array}{c}0.81 \\
(0.05-1.7)\end{array}$ \\
\hline $\begin{array}{l}\text { Chemical oxygen } \\
\text { demand, mg/L }\end{array}$ & $\begin{array}{l}540 \pm 270 \\
(330-1,000)\end{array}$ & $\begin{array}{c}730 \pm 130 \\
(520-900)\end{array}$ & $\begin{array}{c}540 \\
(500-560)\end{array}$ & $\begin{array}{c}380 \\
(0-1,100)\end{array}$ \\
\hline
\end{tabular}

1/ The first set of numbers is the mean and standard deviation; the second set of numbers, in parentheses, is the minimum and maximum values observed.

2/ From trenches 5 years or more old.

3/ From open trenches being filled.

The average concentration and standard deviation of trace metals in wells 2, 3, 4, and 7 and the trenches, as compared to background concentrations from wells 10 through 13 and 16 through 20, are presented in table 6 .

The data indicate that (1) concentrations of trace metals in water from trenches (new and old) were approximately the same as background concentrations, except for zinc; and (2) concentrations of trace metals in wells 2, 3, 4, and 7, except for chromium and probably arsenic and lead were about the same as background levels. The lack of trace metals in the water is probably due to (1) ion-exchange properties of clay minerals (montmorillinite, kaolinite, and illite) in the sediments that were excavated in the construction of the trenches and used as cover material (U.S. Environmental Protection Agency, 1976b); (2) absorption properties of colloidal iron found in the sediments; and (3) organic acid and substances formed by bacterial decomposition of organic matter. 
Table 6.--Statistics of trace metals in water from selected wells and trenches

[All values in micrograms per liter (ug/L)]

\begin{tabular}{|c|c|c|c|c|c|c|c|}
\hline \multirow{2}{*}{$\begin{array}{l}\text { Trace } \\
\text { metal }\end{array}$} & \multicolumn{4}{|c|}{ Landfill wells } & \multirow{2}{*}{$\begin{array}{l}\text { Back- } \\
\text { ground } \\
\text { wells }\end{array}$} & \multicolumn{2}{|c|}{ Trenches } \\
\hline & 2 1/ & 31/ & $41 /$ & 7 至 & & $01 d^{2 /}$ & New ${ }^{3 /}$ \\
\hline Arsenic & $\begin{array}{c}2 \pm 1 \\
(0-4)\end{array}$ & $\begin{array}{l}8 \pm 3 \\
(4-11)\end{array}$ & $\begin{array}{c}1 \pm 1 \\
(0-1)\end{array}$ & $\begin{array}{l}6 \pm 9 \\
(0-22)\end{array}$ & $\begin{array}{c}2 \pm 2 \\
(0-8)\end{array}$ & $\begin{array}{c}2 \\
(1-4)\end{array}$ & $\begin{array}{c}20 \\
(4-61)\end{array}$ \\
\hline Cadmium & $\begin{array}{c}0 \\
(0)\end{array}$ & $\begin{array}{c}1 \pm 2 \\
(0-5)\end{array}$ & $\begin{array}{c}0 \\
(0-1)\end{array}$ & $\begin{array}{c}0 \\
(0-1)\end{array}$ & $\begin{array}{c}1 \pm 1 \\
(0-5)\end{array}$ & $\begin{array}{c}0 \\
(0)\end{array}$ & $\begin{array}{c}2 \\
(0-4)\end{array}$ \\
\hline Chromium & $\begin{array}{c}30 \pm 10 \\
(10-50)\end{array}$ & $\begin{array}{l}70 \pm 20 \\
(50-100)\end{array}$ & $\begin{array}{c}20 \pm 10 \\
(10-40)\end{array}$ & $\begin{array}{c}40 \pm 20 \\
(10-70)\end{array}$ & $\begin{array}{c}20 \pm 20 \\
(<10-110)\end{array}$ & $\begin{array}{c}40 \\
(30-60)\end{array}$ & $\begin{array}{c}140 \\
(20-350)\end{array}$ \\
\hline Copper & $\begin{array}{c}7 \pm 8 \\
(0-22)\end{array}$ & $\begin{array}{l}8 \pm 3 \\
(5-12)\end{array}$ & $\begin{array}{c}4 \pm 2 \\
(1-6)\end{array}$ & $\begin{array}{l}5 \pm 4 \\
(2-11)\end{array}$ & $\begin{array}{c}8 \pm 14 \\
(1-67)\end{array}$ & $\begin{array}{l}13 \\
(6-20)\end{array}$ & $\begin{array}{c}20 \\
(1-66)\end{array}$ \\
\hline Lead & $\begin{array}{l}8 \pm 4 \\
(4-16)\end{array}$ & $\begin{array}{l}40 \pm 40 \\
(4-90)\end{array}$ & $\begin{array}{l}20 \pm 20 \\
(4-66)\end{array}$ & $\begin{array}{l}20 \pm 30 \\
(0-72)\end{array}$ & $\begin{array}{l}30 \pm 30 \\
(0-99)\end{array}$ & $\begin{array}{l}24 \\
(6-40)\end{array}$ & $\begin{array}{c}30 \\
(2-97)\end{array}$ \\
\hline Mercury & $\begin{array}{c}<0.5 \\
(0.0-<0.5\end{array}$ & $\begin{array}{c}<0.5 \\
(0.0-0.6)\end{array}$ & $\begin{array}{c}<0.5 \\
(0.1-<0.5\end{array}$ & $\begin{array}{c}<0.5 \\
(0.1-<0.5)\end{array}$ & $\begin{array}{l}0.5 \pm 0.05 \\
(0-1.4)(\end{array}$ & $\begin{array}{c}0.5 \\
<0.5-0.8)\end{array}$ & $\begin{array}{r}0.5 \\
(0-1.0)\end{array}$ \\
\hline Zinc & $\begin{array}{c}40 \pm 10 \\
(30-50)\end{array}$ & $\begin{array}{c}60 \pm 40 \\
(20-110)\end{array}$ & $\begin{array}{c}30 \pm 20 \\
(10-60)\end{array}$ & $\begin{array}{c}40 \pm 30 \\
(10-80)\end{array}$ & $\begin{array}{l}40 \pm 30 \\
(0-130)\end{array}$ & $\begin{array}{c}70 \\
(20-150)\end{array}$ & $\begin{array}{c}300 \\
(11-790)\end{array}$ \\
\hline
\end{tabular}

1/ The first set of numbers is the mean and standard deviation; the second set, in parentheses, is the minimum and maximum values observed.

2/ From trenches 5 years or more old.

3/ From open trenches being filled.

Graphs showing the variation in concentrations for the selected index parameters are presented in figure 13. The graph of specific conductance shows that maximum levels in well 2 occurred about 1 year before those in well 3 . The same relation occurs for chloride and ammonia nitrogen. Concentrations of all selected parameters, except organic nitrogen, in well 2 reached a peak in mid-1976, prior to receding to near background levels.

The occurrence of peaks is probably the result of slug-flow of leachate from the landfill trenches. Only one peak was apparent during the period of study; however, peaks may have occurred prior to the study period and they may recur. Estimates of the velocity of ground-water flow and leachates from the trenches through the aquifer were made assuming that (1) undisturbed sediments are isotropic and homogeneous; (2) discharge is along the sand marl interface; (3) the constituents in the leachate are conservative ions, such as chloride or other conservative parameters and will move at the same velocity as the ground water. Nonconservative ions may react with surrounding material or may be adsorbed on clays and so forth. Thus, these constituents may move at a much slower rate than the ground water; and (4) the ground-water gradient is that of September 1977.

The velocity of ground-water flow was determined using the hydraulic gradient between well 5b in the center of the landfill and wells 2 and 3 (fig. 14) south of the trenches along 118th Avenue North. 


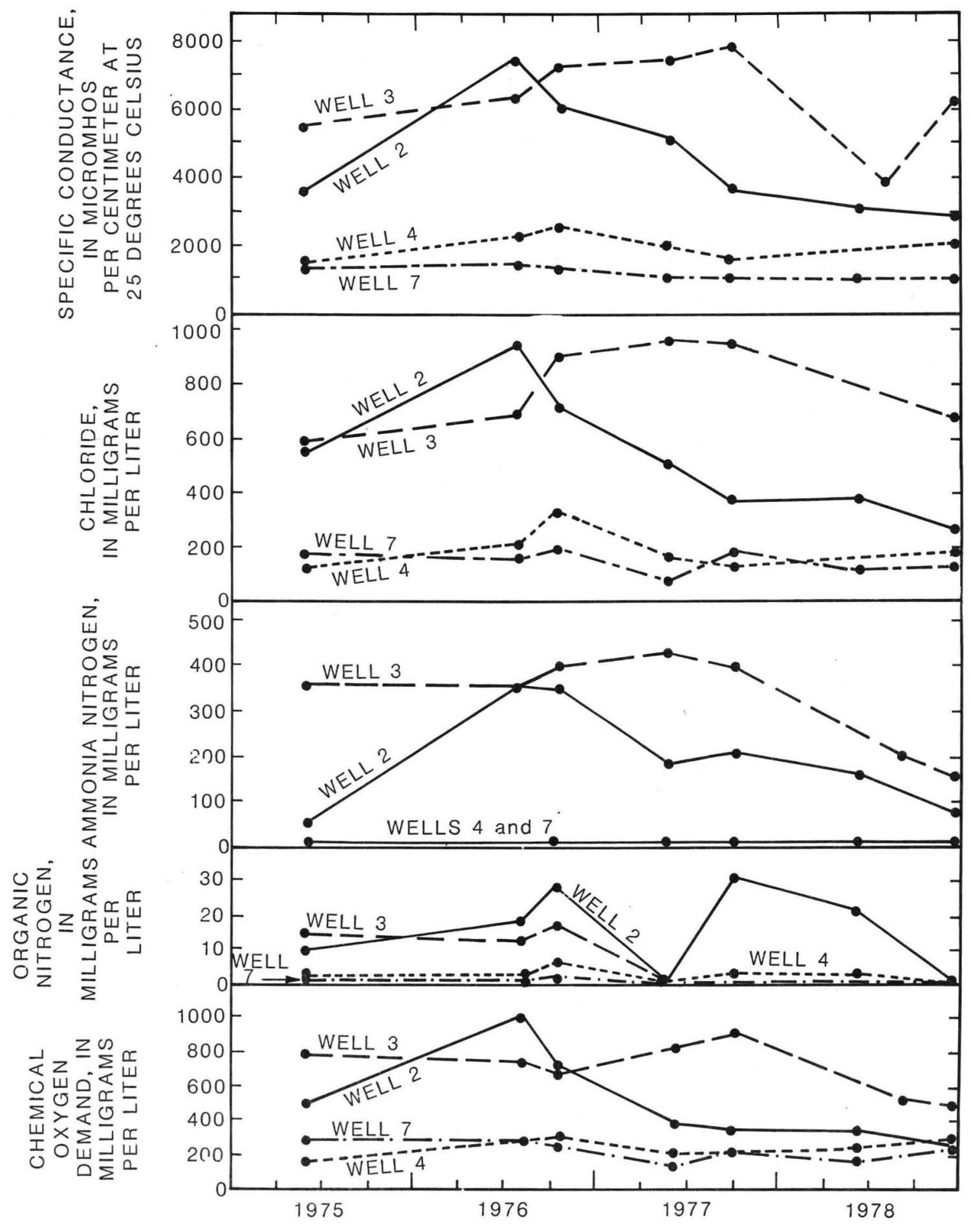

Figure 13.--Variations in selected water-quality parameters with time for wells along 118th Avenue North. 


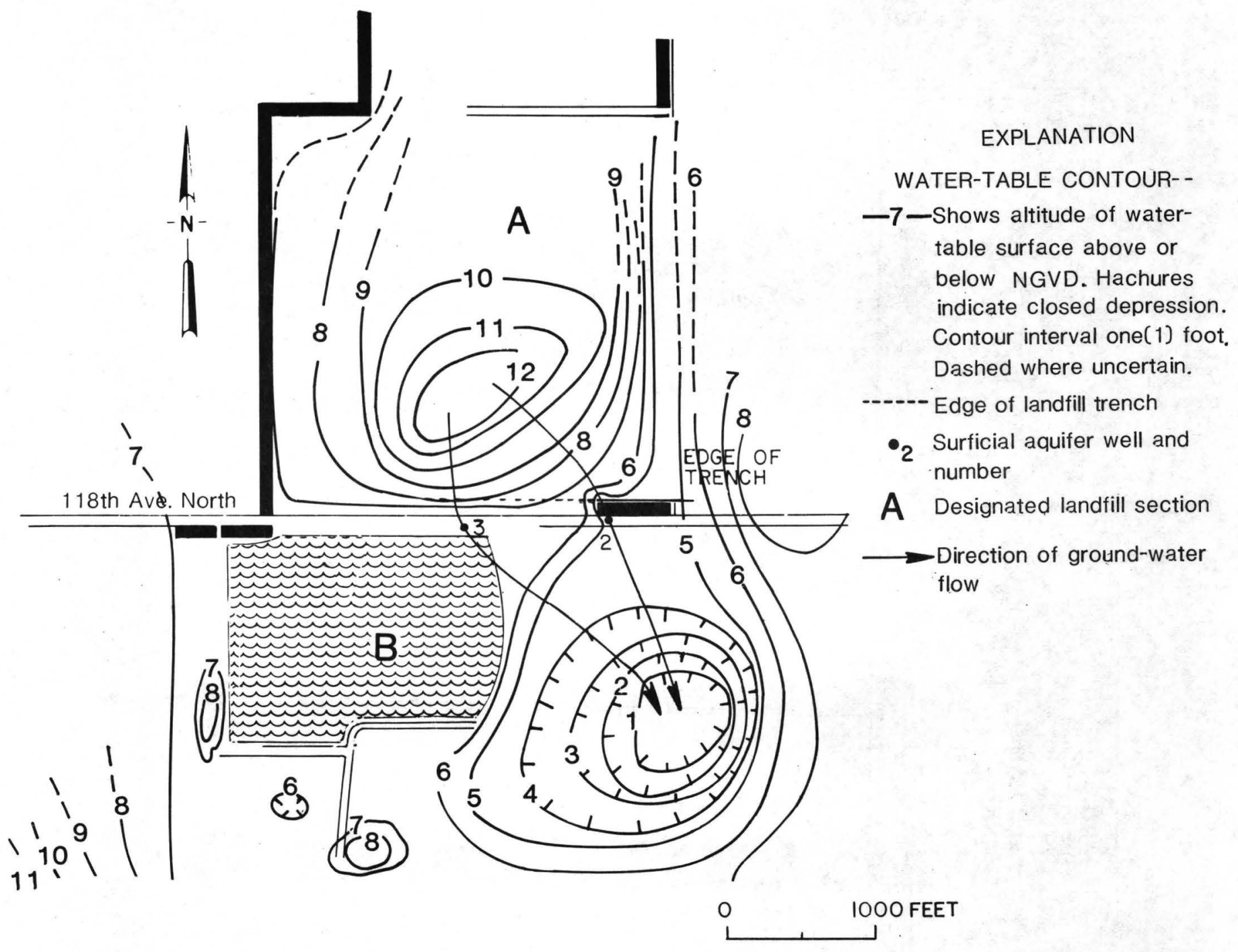

Figure 14.--Direction of leachate movement from site A, September 1977. 
The velocity of ground-water flow through the surficial aquifer toward the wells was calculated using data previously defined and a modified form of Darcy's equation:

$$
v_{h}=\frac{K_{h} I}{n_{e}}
$$

where: $\mathrm{K}_{\mathrm{h}}=$ Average horizontal hydraulic conductivity $(2.1 \mathrm{ft} / \mathrm{d})$;

$I$ = Hydraulic gradient between water-level altitude in landfill

(well 5b) and wells 2 and 3;

$\mathrm{n}_{\mathrm{e}}=$ Average effective porosity of surficial aquifer (0.3).

The hydraulic gradients through wells 2 and 3, determined from water-level data for September 1977, were 0.0062 and $0.0095 \mathrm{ft} / \mathrm{ft}$, respectively. Computed velocities at wells 2 and 3 are as follows:

$$
\begin{aligned}
& \mathrm{V}_{\mathrm{h}_{2}}=\frac{(2.1 \mathrm{ft} / \mathrm{d})(0.0062)(365 \mathrm{~d} / \mathrm{yr})}{0.3}=15.8 \mathrm{ft} / \mathrm{yr} \\
& \mathrm{V}_{\mathrm{h}_{3}}=\frac{(2.1 \mathrm{ft} / \mathrm{d})(0.0095)(365 \mathrm{~d} / \mathrm{yr})}{0.3}=24.3 \mathrm{ft} / \mathrm{yr}
\end{aligned}
$$

The estimated time for ground water to move from the edge of the filled trenches along 118th Avenue North to wells 2 and 3 is computed as follows:

$$
\begin{aligned}
& \text { (wel1 2) } \\
& \text { Time }=\frac{\text { Distance from trench }}{V_{h_{2}}}=\frac{37 \mathrm{ft}}{15.8 \mathrm{ft} / \mathrm{yr}}=2.3 \mathrm{yr} \\
& \text { (wel1 3) } \\
& \text { Time }=\frac{\text { Distance from trench }}{V_{\mathrm{h}_{3}}}=\frac{87 \mathrm{ft}}{24.3 \mathrm{ft} / \mathrm{yr}}=3.6 \mathrm{yr}
\end{aligned}
$$

Thus, under the conditions presented, a slug of leachate, if it moved with the same velocity as ground water, would appear in well 2 about 1.3 years before it appeared in well 3. The lag time between the two wells in the calculated ground-water velocity is close to the approximately 1-year lag time shown by the water-quality parameters in figure 13.

\section{SUMMARY AND CONCLUSIONS}

The Pinellas County landfill site is about 2 miles west of Old Tampa Bay. The site is on a flat, coastal area characterized by a near-surface water table subject to tidal flooding during a 100-year tidal storm event. Altitudes within the study area range from 8 to 12 feet above sea level. Average annual precipitation for November 1974 through June 1978 was 48 inches. Most rainfall occurs during the months of June to October. 
The study area is underlain by four types of sediments: (1) a surficial layer of fine to very fine sand and shell about 19 feet thick; (2) a marl or calcareous clay bed about 10 feet thick; (3) light greenish-gray to grayishblue-green clay about 25 feet thick; and (4) a white, hard chert and fossiliferous limestone. The hydraulic properties of these sediments determine the extent of lateral and vertical migration of the leachate from the landfill.

The four types of sediments constitute three geohydrologic units underlying the landfill site: (1) a surficial aquifer composed of fine sand and shell about 19 feet thick; (2) a confining bed composed of marl and clay about 35 feet thick; and (3) the upper part of the Floridan aquifer composed of limestone about 200 feet thick.

Average ground-water levels in the surficial aquifer at the landfill were 5 feet above sea level in May 1977 and 8 feet above sea level in September 1977. A water-table mound and a cone of depression have developed as a result of the landfill. The mound developed in the northern part of the landfill site where filled trenches have caused a rise in the water table. The cone of depression developed at a private landfill bordering the northwest boundary of section $\mathrm{C}$ because of dewatering operations at a borrow pit used for cover material.

The general regional direction of ground-water movement in the surficial aquifer is northeast toward 0ld Tampa Bay. The rate of horizontal movement is about $1.2 \mathrm{ft} / \mathrm{yr}$. At this rate it would take more than 11,000 years for ground water to travel from the landfill to the bay. The rate of downward vertical migration through the confining bed is about $0.005 \mathrm{ft} / \mathrm{yr}$, requiring about 7,000 years for the ground water to flow through the entire confining bed into the Floridan aquifer. Flow from the bottom of trenches dug through the marl portion of the confining layer would take 3,000 years to reach the Floridan aquifer.

One physical property and four chemical constituents were selected to define surface- and ground-water quality as related to the landfill leachate. The average background values of the constituents and properties of water from areas of the surficial aquifer unaffected by the landfill leachate are: specific conductance, $1,240 \mathrm{umho} / \mathrm{cm}$; chloride, $160 \mathrm{mg} / \mathrm{L}$; organic nitrogen, $0.97 \mathrm{mg} / \mathrm{L}$; ammonia nitrogen, $0.33 \mathrm{mg} / \mathrm{L}$; and chemical oxygen demand, $87 \mathrm{mg} / \mathrm{L}$. The quality of water obtained from a well open to the Floridan aquifer in the northern part of the landfill was tested to determine if short circuiting of flow of leachate occurred through the annular well space or through the confining layer to the Floridan aquifer. Similarity in water quality between water from this well and water from wells in the same strata 10 miles to the west suggests that downward migration along the well annulus or through the confining bed has not occurred.

The quality of water from surficial aquifer wells downgradient of the northern landfill indicates that leachate is moving away from the landfill site. Peak values of water from wells tapping the surficial aquifer in this area are: specific conductance, 7,800 umho/cm; chloride, $960 \mathrm{mg} / \mathrm{L}$; organic nitrogen, $32 \mathrm{mg} / \mathrm{L}$; ammonia nitrogen, $430 \mathrm{mg} / \mathrm{L}$; and chemical oxygen demand, $1,000 \mathrm{mg} / \mathrm{L}$. The time intervals between the measured peak concentrations indicate the possibility of intermittent release of leachate from the landfill. Changes in the quality of surface water that can be related to the leachate have not been detected.

The effect of the Pinellas County landfill on the quality of water in the surficial aquifer presently is confined to within the landfill or the immediate area. Based on rate-of-lateral migration of ground water, about $1.2 \mathrm{ft} / \mathrm{yr}$, the predicted effect of the landfill on the quality of ground water outside the immediate area is negligible. 
Trace metals in the shallow aquifer fall within the values found in background conditions. Thus, the use of trace metals as indicators of landfill leachate migration is not applicable to this study because of the probable absorption of the metals by the clays in the sands of the surficial aquifer.

\section{REFERENCES}

De Wiest, R. J. M., 1965, Geohydrology: New York, John Wiley and Sons, Inc., $366 \mathrm{p}$.

Fernandez, Mario, Jr., 1979a, Ground-water quality data from a sludge disposal test site, St. Petersburg, Florida, November 1973-July 1977: U.S. Geological Survey Open-File Report 78-821, 101 p.

1979b, Water-quality data from a landfill, Pinellas County, Florida, May 1975-October 1977: U.S. Geological Survey Open-File Report 78-822, 97 p.

Florida Department of Environmental Regulation, 1978, Rules of the Department of Environmental Regulation, water-quality standards, Chapter 17-3, in Florida Administrative Code: Tallahassee (in hearing), $43 \mathrm{p}$.

Heath, R. C., and Smith, P. C., 1954, Ground-water resources of Pinellas County, Florida: Florida Geological Survey Report of Investigations 12, 139 p.

Hickey, J. J., 1980, Hydrogeology, estimated impact, and regional well monitoring of effects of subsurface wastewater injection, Tampa Bay area, Florida: U.S. Geologica1 Survey Water-Resources Investigations 80-118, 46 p.

Hutchinson, C. B., and Stewart, J. W., 1978, Hydrogeology of Toytown landfill, St. Petersburg, Florida: U.S. Geological Survey Water-Resources Investigations $77-78,40 \mathrm{p}$.

Rorabaugh, M. I., 1960, Use of water levels in estimating aquifer constants in a finite aquifer: Proceedings of the General Assembly of Helsinki, Commission of Subterranean Waters, International Association of Scientific Hydrology, Publication no. 52, p. 314-323.

Stewart, J. W., and Duerr, A. D., 1973, Hydrologic and geologic considerations for solid-waste disposal in west-central Florida: U.S. Geological Survey Water-Resources Investigations 50-73, 51 p.

U.S. Department of Agriculture, Soil Conservation Service, 1972, Soil survey of Pinellas County, Florida, 64 p., 33 plates.

U.S. Environmental Protection Agency, 1975, Compilation of methodology used for measuring pollution parameters of sanitary landfill leachate: Ecological Series, EPA-600/3-73-011, 174 p.

1976a, Quality criteria for water: EPA-440/9-76-023, 256 p.

1976b, Gas and leachate from landfills, formation, collection and treatment: EPA-600/9-76-004, 196 p.

1977, Procedures manual for ground-water monitoring at solid waste disposal facilities: EPA-530/SW-611, 269 p.

U.S. Geological Survey, 1973a, Map of flood-prone areas, Safety Harbor quadrangle, Florida: U.S. Geological Survey, WRD, Tallahassee, Florida.

1973b, Map of flood-prone areas, St. Petersburg quadrangle, Florida:

U.S. Geological Survey, WRD, Tallahassee, Florida. 